\author{
Krzysztof Jarosiński \\ Benedykt Opałka
}

\title{
FINANSOWANIE PROJEKTÓW INWESTYCYJNYCH NA POZIOMIE LOKALNYM W POLSCE W LATACH 2010-2013
}

\section{Wprowadzenie}

W roku 2010 przyjęto jeden z ważniejszych dokumentów kierunkowych ustalających podstawowe cele rozwoju Unii Europejskiej pod nazwą "Strategia Europa 2020”. Dokument ten stanowi kontynuację polityki rozwoju ujętej wcześniej w strategii lizbońskiej, uwzględnia on jednak zarówno uwarunkowania wypływające z globalnego kryzysu finansowego, jak i negatywne doświadczenia niektórych państw członkowskich, w których kryzys początkowo finansowy przekształcił się w poważny kryzys społeczno-gospodarczy. Strategia Europa 2020 ogniskuje się zasadniczo na trzech najważniejszych zakresach problemowych: rozwoju inteligentnym i rozwoju zrównoważonym oraz działaniach sprzyjających włączeniu społecznemu.

Na gruncie krajowym w odniesieniu do poszczególnych państw członkowskich Unii Europejskiej postulaty stawiane w Strategii Europa 2020 mogą być jednak postrzegane w różny sposób. Dlatego też wraz ze wspomnianym dokumentem w Polsce opracowano Krajowy Program Reform Europa 2020, który w sposób sekwencyjny ma doprowadzić do osiągnięcia celów na gruncie polskim. Sekwencyjny charakter Krajowego Programu Reform polega na tym, że jest on aktualizowany najpóźniej wiosną kolejnego roku programowania. Począwszy od roku 2010, obserwuje się wyraźne przeorientowanie celów stawianych projektom inwestycyjnym oraz innym przedsięwzięciom w kierunku osiągania celów wyszczególnionych w Strategii. Proces ten jest wyraźnie widoczny w Polsce, jeśli weźmie się pod uwagę tematykę zgłaszanych projektów oraz określone w nich cele.

W opracowaniu przedstawiono zatem wyniki badań regionalnych stanowiące kontynuację badań podjętych w roku 2013 w ramach SGH we współpracy z Ministerstwem Infrastruktury i Rozwoju. Badaniem objęto cztery powiaty: lubelski, opolski, wejherowski oraz wołomiński, a także wszystkie gminy wchodzące w skład tych powiatów, 
tj. w przypadku powiatu lubelskiego badaniem objęto 16 gminnych jednostek samorządu terytorialnego, w przypadku powiatu opolskiego - 13 gminnych jednostek samorządu terytorialnego, w przypadku powiatu wejherowskiego - 10 gminnych jednostek samorządu terytorialnego oraz w przypadku powiatu wołomińskiego 12 gminnych jednostek samorządu terytorialnego. Oznacza to, że przedmiotem badania w aspekcie celów Strategii Europa 2020 była analiza projektów współfinansowanych ze środków unijnych, które wpisują się zarówno w priorytety Strategii, jak i nadrzędne cele Unii Europejskiej w perspektywie do $2020 \mathrm{r}$.

Ogółem badaniem objęto zatem 4 powiatowe jednostki samorządu terytorialnego, 51 gminnych jednostek samorządu terytorialnego oraz wszystkie podmioty gospodarcze w układzie gminnym, które rozpoczęły realizację projektów współfinansowanych ze środków unijnych w roku 2010. Część z projektów została już zakończona, inne są nadal realizowane. Biorąc pod uwagę cel badania, szczególną uwagę zwrócono na wartość projektu ogółem oraz wartość zakontraktowanego dofinansowania. Większy stopień szczegółowości odnośnie do projektów na tym etapie badania nie może być osiągnięty. Mając na uwadze wytyczne Strategii oraz wyznaczone priorytety, w badaniu przedstawiono w ujęciu wartościowym wydatki w podziale na następujące grupy projektów: „Badania i wspieranie innowacyjności”, „Poprawa systemów kształcenia”, „Upowszechnienie internetu i cyfryzacja”, „Efektywne wykorzystanie zasobów”, „Wsparcie dla biznesu (w tym MŚP)”, „Modernizacja rynku pracy”, „Rozwój umiejętności i zatrudnienie”, „Zapewnienie spójności społecznej i terytorialnej” oraz „Inne projekty”.

\section{Uwarunkowania i finansowanie rozwoju lokalnego i regionalnego}

Wyznaczanie kierunków rozwoju regionalnego oraz finansowanie przedsięwzięć rozwojowych w skali regionów ciągle pozostaje ważnym zagadnieniem w sferze teoretycznej i praktycznej, zarówno w Unii Europejskiej, jak i w poszczególnych krajach członkowskich. Zagadnieniom tym poświęcone zostały liczne prace naukowo-badawcze, a ponadto koncepcja polityki regionalnej ulegała ewolucji także w wymiarze praktycznym, będąc przedmiotem działań o charakterze administracyjnym i gospodarczym podejmowanych w wielowymiarowej skali. W dotychczasowym przebiegu powyższych zjawisk, wobec ograniczonej skuteczności form zewnętrznego stymulowania procesu rozwoju regionalnego pojawiła się potrzeba określenia innych 
zasad, które zapewniłyby realne podstawy do działań na rzecz zmniejszania skali zróżnicowań społeczno-gospodarczych regionów w obrębie poszczególnych państw oraz większych obszarów objętych powiązaniami politycznymi i gospodarczymi ${ }^{1}$. Jak wskazuje P. Churski, odpowiedzi na ww. problemy można odnaleźć w założeniach nowej teorii wzrostu oraz nowej geografii ekonomicznej, w których to podejściach teoretycznych uznawana jest szczególna rola endogenicznych zasobów fizycznych i społecznych dla rozwoju regionu, a wywodząca się z tego nurtu koncepcja polityki regionalnej traktuje rozwój gospodarczy jako efekt wewnętrzny, ukształtowany oddolnie w danym regionie ${ }^{2}$.

Rozwój regionalny w Polsce kształtowany jest poprzez działania podejmowane na dwóch poziomach, tj. polityki regionalnej prowadzonej przez administrację rządową oraz polityki rozwoju w poszczególnych regionach prowadzonej przez samorząd terytorialny województwa. Podział kompetencji w powyższym zakresie wynika zarówno z ustawy z dnia 6 grudnia $2006 \mathrm{r}$ o zasadach prowadzenia polityki rozwoju, jak i ustawy z dnia 5 czerwca 1998 r. o samorządzie województwa oraz innych rozwiązań administracyjno-prawnych, stopniowo wypracowywanych i wdrażanych w ramach realizacji polityki spójności finansowanej w znacznej części ze środków budżetowych Unii Europejskiej.

Ważne funkcje koordynujące względem szeregu działań o charakterze rozwojowym pełni samorząd województwa. Dotyczy to m.in. zadań realizowanych przez władze samorządowe gmin i powiatów. Należy podkreślić, że koordynacja ta odbywa się przede wszystkim w wymiarze finansowym, poprzez redystrybucję środków unijnych $\mathrm{w}$ trybie konkursowym do jednostek samorządu terytorialnego na poziomie lokalnym, zgodnie z kierunkami rozwoju regionu ustalonymi w strategiach wojewódzkich i regionalnych programach operacyjnych. Wzrost znaczenia roli samorządu wojewódzkiego zaplanowany został w systemie realizacji polityki spójności w perspektywie finansowej UE 2007-2013, realnie jednak następował od roku 2009, kiedy zostały doprecyzowane zasady redystrybucji środków unijnych oraz uruchomione procesy finansowania przedsięwzięć inwestycyjnych o wymiarze zarówno regionalnym, jak i na poziomie lokalnym. Należy zauważyć, że zakres wsparcia przy wykorzystaniu środków unijnych, realizowanego w ramach działalności samorządu

${ }^{1}$ K. Jarosiński, B. Opałka, Finansowanie projektów rozwojowych na poziomie regionalnym i lokalnym $w$ Polsce a założenia Strategii Europa 2020, w: Strategia Europa 2020 a gospodarka regionalna i lokalna w Polsce, pr. zb. pod red. Z. Strzeleckiego, Ministerstwo Infrastruktury i Rozwoju, Warszawa 2014, s. 32-33.

2 P. Churski, Czynniki rozwoju regionalnego w świetle koncepcji teoretycznych, „Zeszyty Naukowe Wyższej Szkoły Humanistyczno-Ekonomicznej we Włocławku. Nauki Ekonomiczne” t. XIX, z. 3: Gospodarka regionu na Jednolitym Rynku Europejskim. Wybrane zagadnienia, Włocławek 2005, s. 25. 
terytorialnego województwa, obejmuje nie tylko przedsięwzięcia podejmowane przez jednostki sektora publicznego, ale w znacznym zakresie skierowany jest na zwiększanie poziomu inwestycji w sektorze prywatnym, służąc w tym obszarze głównie wspieraniu powstawania lub rozwoju małych i średnich przedsiębiorstw.

W przypadku zadań jednostek organizacyjnych sektora publicznego zasady finansowania określone są $\mathrm{w}$ formie ustawowej. Tak więc finansowanie rozwoju w zakresie odpowiadającym kompetencjom poszczególnych kategorii podmiotów sektora publicznego zasadniczo uwarunkowane jest zasobami budżetowymi i zalicza się bezpośrednio do gospodarki budżetowej. Nieco inaczej wygląda sytuacja przedsiębiorstw sektora finansów publicznych zorganizowanych $\mathrm{w}$ formie spółek kapitałowych, jednak i tam dominujące źródło ich finansowania zarówno w ujęciu bieżącym, jak i rozwojowym zasadniczo stanowią środki budżetowe. Co prawda w komunalnych spółkach kapitałowych czy innych spółkach o charakterze publicznym dąży się do jak największej samodzielności finansowej tych podmiotów, jednak ich status i charakter działalności przesądza o charakterze powiązań kapitałowych z jednostkami sektora publicznego. Z chwilą przystąpienia Polski do Unii Europejskiej zarządzanie i finansowanie jednostek samorządu terytorialnego stało się zagadnieniem bardziej złożonym. Obok środków tradycyjnie uznawanych za budżetowe, a więc pochodzących z podatków, opłat, udziałów, pojawiły się strumienie pieniężne, z których niekiedy samorząd terytorialny w Polsce nigdy nie korzystał. Należy zwrócić uwagę zwłaszcza na kredyty o charakterze inwestycyjnym, obligacje komunalne, dotacje celowe $\mathrm{z}$ budżetu państwa oraz wsparcie $\mathrm{w}$ ramach środków budżetowych Unii Europejskiej.

Niezależnie od sytuacji gospodarczej w obecnej chwili za istotne źródło finansowania lub dofinansowania inwestycji w jednostkach samorządu terytorialnego należy uznać środki o charakterze bezzwrotnym, których dostępność wywołuje określone skutki ekonomiczne wynikające z pojawienia się kapitału (najczęściej inwestycyjnego) charakteryzującego się niskim poziomem obciążenia istotnymi kosztami jego pozyskania. Wsparcie finansowe przekazywane w formie bezzwrotnej stanowi dla jednostek samorządu terytorialnego bardzo korzystne źródło zasilania budżetów, które może być wykorzystane na cele finansowania zdefiniowanych projektów rozwojowych w obszarze infrastruktury lub innych istotnych zasobów gospodarki regionalnej i lokalnej. Środki o charakterze bezzwrotnym powinny być zatem wykorzystywane przez jednostki samorządu terytorialnego na realizację przedsięwzięć głównie w sferze infrastruktury społeczno-gospodarczej, a także w zakresie poprawy funkcjonowania samorządowej administracji publicznej. Zadania w wymienionej sferze muszą być podjęte z uwagi na zobowiązania wynikające z członkostwa Polski w Unii 
Europejskiej oraz wymogi polityki spójności. Możemy zatem przyjąć, że zadania powinny prowadzić do wymiernych korzyści na poziomie regionalnym i lokalnym, a także powinny stanowić wartość dodaną w skali całej Unii ${ }^{3}$.

Warto przypomnieć, że w okresie programowania 2007-2013 cele Unii ukierunkowane zostały na osiągnięcie trwałego i zrównoważonego postępu społeczno-gospodarczego oraz wzmocnienie spójności ekonomicznej i społecznej (zgodnie z art. 2 Traktatu o Unii Europejskiej), co m.in. wiązało się z dostępnością szerokiego zakresu możliwości wspierania rozwoju społeczno-gospodarczego w Polsce w ramach pomocy ze środków budżetu UE. W kolejnym okresie programowania 2014-2020 wsparcie ze strony UE będzie kształtować się również na wysokim poziomie, przy czym Polska może otrzymać 105,8 mld euro, w tym na politykę spójności około 72,9 mld euro.

Doświadczenia kończącego się okresu programowania wskazują, że wobec realnego ryzyka ograniczania poziomu dochodów własnych samorządu terytorialnego środki unijne mogą mieć istotny pozytywny wpływ na rozwój regionów i lokalnych jednostek samorządowych, zarówno w wymiarze finansów publicznych, jak i pośrednio mogą wzmacniać koniunkturę gospodarczą i tworzyć pewnego rodzaju bufor ograniczający wpływ zjawisk kryzysowych na sektor prywatny. Należy przy tym pamiętać o negatywnych zjawiskach związanych ze światowym kryzysem finansowym, który zachwiał dotychczasową strukturą finansów publicznych w Unii Europejskiej. Konieczność weryfikacji dotychczasowych planów rozwojowych z uwagi na ograniczone zasoby finansowe w zupełnie nowym świetle stawia procesy rozwojowe w Polsce. Ponownie zatem należy zwrócić uwagę na Krajowy Program Reform Europa 2020 oraz jego aktualizacje. W szczególności należy wspomnieć o utworzeniu programu Polskie Inwestycje, a także o wielu innych inicjatywach, które rozpoczęły się w roku 2013 i będą kontynuowane w kolejnych latach.

\section{Charakterystyka nakładów na zadania realizowane w ramach Strategii Europa 2020}

Zgodnie z wytycznymi Strategii na rzecz inteligentnego i zrównoważonego rozwoju sprzyjającego włączeniu społecznemu Europa 2020, począwszy od 2010 r., wyraźnie obserwuje się zmianę priorytetów i co za tym idzie orientacji projektów

${ }^{3}$ K. Jarosiński, B. Opałka, op.cit., s. 33. 
zgłaszanych do wsparcia w ramach funduszy strukturalnych Unii Europejskiej. Nowa orientacja projektów wynika z potrzeby sprostania szeregu wyzwaniom o charakterze rozwojowym, wśród których należy wskazać średniookresowe skutki kryzysu finansowego oraz nadal utrzymującą się potrzebę kontynuowania polityki spójności w ramach struktur Unii Europejskiej. Druga połowa pierwszej dekady XXI w. charakteryzowała się w Polsce różnokierunkowymi zmianami. Z jednej strony obserwowaliśmy przyspieszenie wzrostu gospodarczego, stymulowane instrumentami polityki regionalnej Unii Europejskiej. Z drugiej jednak strony, zwłaszcza w latach 2009-2010, ujawniły się zjawiska kryzysowe.

Powyższe zjawiska uświadomiły społeczeństwom, że w nowych warunkach gospodarowania chodzi zarówno o osiąganie celów krótko- i średniookresowych, jak i że konieczne jest spojrzenie długookresowe, o charakterze strategicznym. Nie ulega zatem wątpliwości, że Strategia Europa 2020 wyznacza ważne cele, tak aby w kolejnych latach możliwy był rozwój zrównoważony oraz aby przyjęte zasady działania umożliwiły wyzwolenie gospodarki europejskiej z negatywnie oddziałujących skutków kryzysu. Szczególne znaczenie w tym procesie powinny mieć trzy priorytety rozwojowe zdefiniowane we wspomnianym dokumencie.

Zgodnie ze strukturą dokumentu Strategia Europa 2020 ważną pozycję zajmują „projekty przewodnie”, które stanowią rozwinięcie trzech głównych priorytetów Strategii ${ }^{4}$.

W badaniu wzięto pod uwagę wszystkie projekty, na które zawarto umowy o dofinansowanie $w$ trzech przekrojach: na poziomie administracji powiatowego samorządu terytorialnego oraz powiązanych przedsiębiorstw użyteczności publicznej, na poziomie administracji gminnego samorządu terytorialnego oraz powiązanych przedsiębiorstw komunalnych, a także, jak wspomniano wyżej, wszystkie projekty z sektora prywatnego. Ogólem badaniem objęto 892 projekty. Stosunkowo duża liczba projektów zestawionych w trakcie badania z jednej strony stanowiła trudność metodologiczną w zakresie zapewnienia porównywalności uzyskanych wyników, z drugiej zaś dawała podstawy do wnikliwych i pogłębionych badań nad problematyką finansowania projektów unijnych oraz urzeczywistniania celów wynikających ze Strategii Europa 2020.

Dane liczbowe ilustrujące wydatki unijne ogółem w powiecie lubelskim na rzecz projektów realizowanych pod kątem celów Strategii Europa 2020 przedstawiono $\mathrm{w}$ tabeli 1 oraz zilustrowano na rysunku 1 . Wydatki te obejmują wartość projek-

\footnotetext{
${ }^{4}$ Strategia na rzecz inteligentnego i zrównoważonego rozwoju sprzyjającego włączeniu społecznemu Europa 2020, Komunikat Komisji Europejskiej z dnia 3.03.2010 r., Bruksela 2010, s. 6.
} 
tów ogółem objętych umowami o dofinansowanie w powiatowym oraz gminnym samorządzie terytorialnym, a także w sferze przedsiębiorstw.

Tabela 1. Wydatki ogółem w powiecie lubelskim na realizację projektów zbieżnych z celami Strategii Europa 2020 (w zl)

\begin{tabular}{|l|r|r|r|r|}
\hline \multicolumn{1}{|c|}{ Wyszczególnienie } & Wartość ogółem & $\begin{array}{c}\text { Wydatki } \\
\text { kwalifikowane }\end{array}$ & Dofinansowanie & $\begin{array}{c}\text { Dofinansowanie } \\
\text { UE }\end{array}$ \\
\hline Badania i wspieranie innowacyjności & 182359856,6 & 148834937,7 & 70195097,4 & 59665832,6 \\
\hline Poprawa systemów kształcenia & 13702121,4 & 12757651,7 & 10206121,3 & 10206121,3 \\
\hline $\begin{array}{l}\text { Upowszechnienie internetu } \\
\text { i cyfryzacja }\end{array}$ & 16538456,5 & 16293329,8 & 13856223,1 & 13602567,1 \\
\hline Efektywne wykorzystanie zasobów & 95318999,2 & 81770178,6 & 60588818,8 & 60486382,4 \\
\hline Wsparcie dla biznesu (w tym MŚP) & 342269876,4 & 189784168,6 & 119788509,9 & 102954308,0 \\
\hline $\begin{array}{l}\text { Modernizacja rynku pracy, rozwój } \\
\text { umiejętności i zatrudnienie }\end{array}$ & 0,0 & 0,0 & 0,0 & 0,0 \\
\hline $\begin{array}{l}\text { Zapewnienie spójności społecznej } \\
\text { i terytorialnej }\end{array}$ & 16775638,4 & 16185966,3 & 13743185,1 & 13743185,1 \\
\hline Inne projekty & 137314539,6 & 120752021,7 & 79197116,8 & 79197116,8 \\
\hline Ogółem & 804279488,1 & 586378254,4 & 367575072,5 & 339855513,3 \\
\hline
\end{tabular}

Źródło: Opracowanie własne na podstawie bieżącej ewidencji oraz stanu realizacji projektów finansowanych ze środków unijnych w ramach Krajowego Systemu Informatycznego, MRR, Warszawa 2013.

W powiecie lubelskim wartość projektów, dla których podpisano umowę lub aneks do umowy począwszy od roku 2010, wyniosła ogółem 804,2 mln zł, z czego dofinansowanie Unii Europejskiej w tym czasie wyniosło 339,8 mln zł. Spośród wymienionych wyżej kategorii najwięcej środków skierowano na przedsięwzięcia w sferze „Wsparcie dla biznesu (w tym MŚP)”. Na tę kategorię projektów podpisano umowy na łączną kwotę 342,2 mln zł, przy jednoczesnym planowanym dofinansowaniu na poziomie 102,9 mln zł. Drugą znaczącą pozycję stanowiły przedsięwzięcia w sferze badań oraz wspierania innowacyjności w gospodarce. Ogólna wartość zawartych umów w tej kategorii wyniosła 182,3 mln zł, przy dofinansowaniu ze strony Unii Europejskiej na poziomie 59,6 mln zł. 
Rysunek 1. Struktura wydatków w powiecie lubelskim według kategorii celów Strategii Europa 2020 oraz dofinansowanie projektów współfinansowanych ze środków UE (w \%)

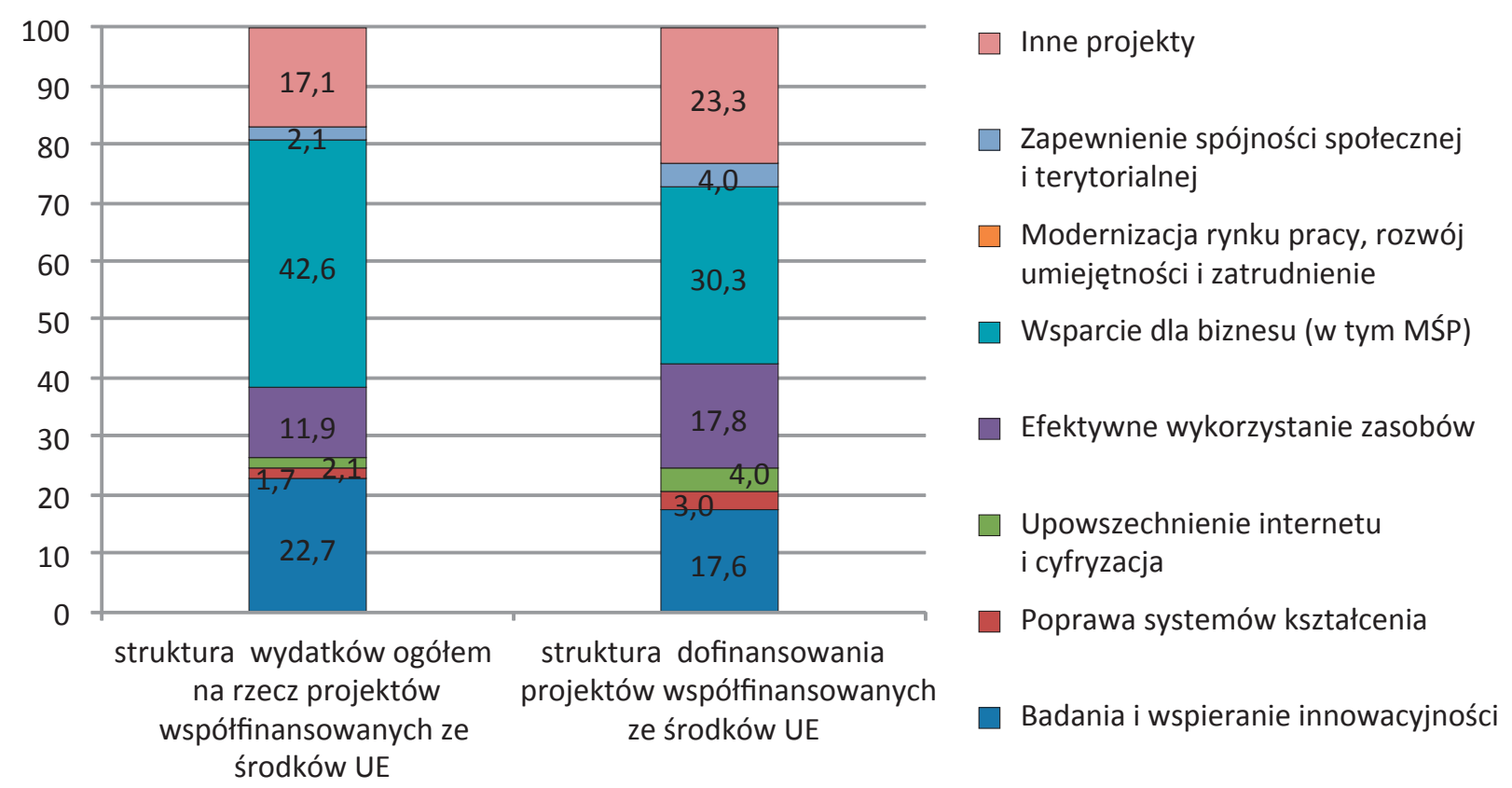

Źródło: Opracowanie własne na podstawie bieżącej ewidencji oraz stanu realizacji projektów finansowanych ze środków unijnych w ramach Krajowego Systemu Informatycznego, MRR, Warszawa 2013.

Znaczącą kategorią była zdefiniowana w badaniu kategoria „Inne projekty”. Utworzenie tej kategorii na potrzeby analizy miało na celu kwalifikację wydatków związanych z projektami, które $\mathrm{z}$ uwagi na swój charakter nie mieściły się $\mathrm{w} 7$ priorytetach tematycznych przedstawionych przez Komisję Europejską w Strategii Europa 2020. Jest w pełni zrozumiałe, że nie wszystkie projekty, począwszy od roku 2010, były bezpośrednio związane z priorytetami Strategii i nie wiązały się z wytyczonymi w niej celami. Do tej kategorii zaliczono głównie projekty z zakresu infrastruktury drogownictwa czy szerzej transportu. Nie umniejszając roli oraz znaczenia tego rodzaju przedsięwzięć, włączono je do odrębnej kategorii „Inne projekty”, co ułatwiło rozpoznanie zakresu merytorycznego projektów pozostałych i zakwalifikowanie ich do poszczególnych priorytetów tematycznych Strategii. W wymienionej grupie projektów na realizację zadań podpisano umowy na łączną kwotę 137,3 mln zł, przy równoczesnym zapewnieniu zawartego w tej wartości dofinansowania w kwocie 79,2 $\mathrm{mln} \mathrm{z}^{5}$. Udział dofinansowania projektów rozwojowych w poszczególnych kategoriach opisujących cele Strategii Europa 2020 przedstawiono graficznie na rysunku 2.

5 Zobacz także K. Jarosiński, B. Opałka, op.cit., s. 37. 
Rysunek 2. Dofinansowanie ogółem projektów rozwojowych w powiecie lubelskim ze środków UE według kategorii celów Strategii Europa 2020 (w \%)

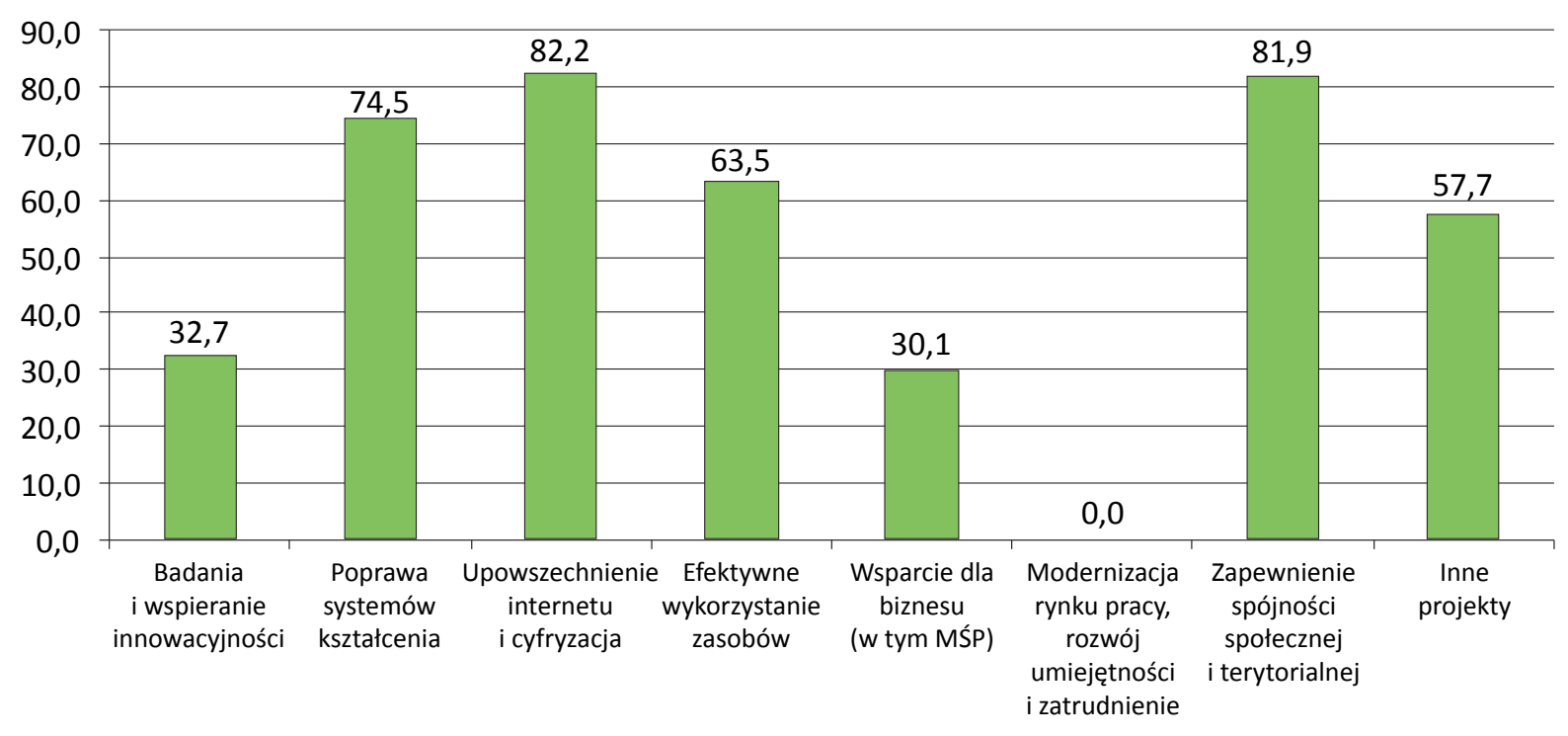

Źródło: Jak do rysunku 1.

Niepokojącym zjawiskiem wydaje się być pominięcie modernizacji rynku pracy oraz rozwoju umiejętności i co za tym idzie oddziaływania na poziom zatrudnienia. W tej grupie nie odnotowano jak dotychczas w latach 2010-2013 projektów związanych z tą problematyką. Chodziłoby tutaj o rozpoznanie i wskazanie tych projektów, które przyczyniałyby się do rozwoju oraz przemian rynku pracy, zmiany pozycji pracobiorców na rynku pracy poprzez kształtowanie nowych kwalifikacji, a także projektów, które prowadziłyby do poprawy współczynnika aktywności zawodowej oraz poprawy relacji podaży i popytu ${ }^{6}$. Nie oznacza to jednak, że w projektach ujętych $\mathrm{w}$ pozostałych grupach problematyka zatrudnienia oraz kształtowania rynku pracy została całkowicie pominięta. Podejmowanie nowych zadań oraz realizacja projektów inwestycyjnych w oczywisty sposób muszą prowadzić do oddziaływania na rynek pracy. Zatem wydatki na rozwój nie mogą nie oddziaływać w sposób pozytywny na zjawiska zachodzące w sferze kwalifikacji zawodowych, potencjału zawodowego i w konsekwencji zatrudnienia. W badaniu nie stwierdzono jedynie projektów stricte poświęconych temu zagadnieniu, które byłyby podejmowane na poziomie powiatowych i gminnych jednostek samorządu terytorialnego oraz w sferze przedsiębiorstw. Problematyka zatrudnienia jest zjawiskiem skomplikowanym i nie należy się dziwić, że na poziomie gminy nie są generowane projekty głębiej w nią wnikające. W tym samym czasie wartość projektów ogółem związanych z poprawą systemu kształcenia,

6 Strategia na rzecz..., op.cit., s. 5. 
a także ułatwienia wejścia ludziom młodym na rynek pracy wyniosła 13,7 mln zł, natomiast wartość dofinansowania tych projektów wyniosła 10,2 mln zł. Na uwagę zasługuje również uruchomienie projektów związanych z upowszechnianiem internetu, cyfryzacją oraz zapewnieniem spójności terytorialnej i społecznej, odpowiednio $16,5 \mathrm{mln}$ zł oraz $16,8 \mathrm{mln} \mathrm{z}$.

Jak wspomniano wcześniej, istotną grupę pomiotów objętych badaniem pod kątem wydatków unijnych kierowanych na urzeczywistnianie celów wynikających z zapisów Strategii Europa 2020 stanowią powiatowe jednostki samorządu terytorialnego. Zgodnie z tabelą 2 ogółem w latach 2010-2013 umowami objęto projekty o łącznej wartości nieco ponad 141,5 mln zł. W tym czasie łączna wartość dofinansowania ze środków unijnych wyniosła powyżej $91 \mathrm{mln}$ zł. Najważniejszą grupą objętą wsparciem było „Efektywne wykorzystanie zasobów”, a więc grupa projektów na rzecz wspierania wzrostu gospodarczego poprzez lepsze wykorzystanie zasobów, w tym zwłaszcza wykorzystanie odnawialnych źródeł energii, modernizację transportu czy też przejście na gospodarkę niskoemisyjną. Drugą co do wartości grupę projektów objętych wsparciem stanowiły „Upowszechnianie internetu i cyfryzacja”. Na tę grupę projektów zawarto umowy na łączną kwotę niemal 12,3 mln zł, przy czym w kwocie tej wsparcie unijne zostało zaplanowane na poziomie 10,4 mln zł. Stosunkowo niewielka kwota objęła projekty na rzecz „Wsparcia dla biznesu (w tym MŚP)”. Dość znaczącą pozycję stanowiły projekty na rzecz „Zapewnienia spójności społecznej i terytorialnej", ogólna wartość umów w tej grupie przedsięwzięć zamknęła się kwotą 4,4 mln zł, przy dofinansowaniu unijnym ustalonym na poziomie 3,4 mln zł. Znaczącą pozycję w strukturze wydatków ogółem stanowiły projekty ujęte w badaniu w kategorii „Inne projekty”. W badanym okresie odnotowano ogólną wartość umów na poziomie 78,5 mln zł, przy czym dofinansowanie unijne kształtowało się na poziomie 44,4 mln zł. Wobec Strategii Europa 2020 nie wszystkie projekty skierowane do realizacji i dofinansowywane ze środków unijnych spełniały wymogi celów tego dokumentu. W kategorii „Inne projekty” znalazły się zatem projekty o charakterze infrastrukturalnym głównie w sferze drogownictwa oraz tych składników infrastruktury, które wchodzą w zakres zadań własnych powiatów. 
Tabela 2. Wydatki unijne powiatu lubelskiego na rzecz projektów przewodnich realizowanych zgodnie z celami Strategii Europa 2020 (w zł)

\begin{tabular}{|l|c|c|c|c|}
\hline \multicolumn{1}{|c|}{ Wyszczególnienie } & Wartość ogółem & $\begin{array}{c}\text { Wydatki } \\
\text { kwalifikowane }\end{array}$ & Dofinansowanie & $\begin{array}{c}\text { Dofinansowanie } \\
\text { UE }\end{array}$ \\
\hline Badania i wspieranie innowacyjności & 0,0 & 0,0 & 0,0 & 0,0 \\
\hline Poprawa systemów kształcenia & 0,0 & 0,0 & 0,0 & 0,0 \\
\hline $\begin{array}{l}\text { Upowszechnienie internetu } \\
\text { i cyfryzacja }\end{array}$ & 12246923,9 & 12204824,4 & 10374100,7 & 10374100,7 \\
\hline Efektywne wykorzystanie zasobów & 46138750,6 & 44674750,6 & 32809136,8 & 32809136,8 \\
\hline Wsparcie dla biznesu (w tym MŚP) & 210363,4 & 199999,1 & 139999,3 & 139999,3 \\
\hline $\begin{array}{l}\text { Modernizacja rynku pracy, rozwój } \\
\text { umiejętności i zatrudnienie }\end{array}$ & 0,0 & 0,0 & 0,0 & 0,0 \\
\hline $\begin{array}{l}\text { Zapewnienie spójności społecznej } \\
\text { i terytorialnej }\end{array}$ & 4436080,0 & 3975056,9 & 3363912,2 & 3363912,2 \\
\hline Inne projekty & 78497655,0 & 68354585,8 & 44398590,1 & 44398590,1 \\
\hline Ogółem & 141529772,9 & 129409216,7 & 91085739,1 & 91085739,1 \\
\hline
\end{tabular}

Źródło: Jak do tabeli 1.

Osobną kategorię projektów objętych dofinansowaniem ze środków unijnych stanowiły przedsięwzięcia realizowane przez gminne jednostki samorządu terytorialnego. Ogółem na terenie powiatu lubelskiego w gminach podpisano umowy na łączną wartość projektów w wysokości 116,2 mln zł. Największą wartość projektów odnotowano w grupie „Efektywne wykorzystanie zasobów” - 47,8 mln zł. Drugą co do wielkości grupę projektów zbieżnych z celami Strategii Europa 2020, poza kategorią „Inne projekty”, stanowiły wydatki zaplanowane po roku 2010 na „Poprawę systemów kształcenia” oraz na „Zapewnienie spójności społecznej i terytorialnej”, odpowiednio 13,7 mln zł oraz 12,3 mln zł.

Zjawiskiem dość specyficznym był brak wydatków związanych z projektami ujętymi w grupach: „Badania i wspieranie innowacyjności”, „Wsparcie dla biznesu (w tym MŚP)” oraz „Modernizacja rynku pracy, rozwój umiejętności i zatrudnienie”. Należy pamiętać, że część celów związanych z wymienionymi trzema kategoriami przejęły na siebie przedsiębiorstwa prywatne funkcjonujące na terenie gmin powiatu lubelskiego. Szczegółowe dane dotyczące wydatków unijnych gmin powiatu lubelskiego na rzecz projektów przewodnich realizowanych zgodnie z celami Strategii Europa 2020 przedstawiono w tabeli 3. W tym miejscu warto zaznaczyć, że w prezentowanym materiale empirycznym przedstawiono również wsparcie realizowanych projektów udzielone $\mathrm{z}$ innych źródeł. Przedstawiono także w odniesieniu do wszystkich jednostek osadniczych poddanych analizie oraz pomiotów gospodarczych wydatki kwalifikowane, a więc te, które były w pełni zgodne z kosztorysami oraz warunkami realizacji projektów. 
Tabela 3. Wydatki unijne gmin powiatu lubelskiego na rzecz projektów przewodnich realizowanych zgodnie z celami Strategii Europa 2020 (w zl)

\begin{tabular}{|l|c|c|c|c|}
\hline \multicolumn{1}{|c|}{ Wyszczególnienie } & Wartość ogótem & $\begin{array}{c}\text { Wydatki } \\
\text { kwalifikowane }\end{array}$ & Dofinansowanie & $\begin{array}{c}\text { Dofinansowanie } \\
\text { UE }\end{array}$ \\
\hline $\begin{array}{l}\text { Badania i wspieranie } \\
\text { innowacyjności }\end{array}$ & 0,0 & 0,0 & 0,0 & 0,0 \\
\hline Poprawa systemów kształcenia & 13702121,4 & 12757651,7 & 10206121,3 & 10206121,3 \\
\hline $\begin{array}{l}\text { Upowszechnienie internetu } \\
\text { i cyfryzacja }\end{array}$ & 3404738,2 & 3404006,2 & 3087932,8 & 2893405,3 \\
\hline $\begin{array}{l}\text { Efektywne wykorzystanie } \\
\text { zasobów }\end{array}$ & 47777772,5 & 35970386,1 & 27096773,1 & 27096773,1 \\
\hline $\begin{array}{l}\text { Wsparcie dlla biznesu } \\
\text { (w tym MŚP) }\end{array}$ & 0,0 & 0,0 & 0,0 & 0,0 \\
\hline $\begin{array}{l}\text { Modernizacja rynku pracy, rozwój } \\
\text { umiejętności i zatrudnienie }\end{array}$ & 0,0 & 0,0 & 0,0 & 0,0 \\
\hline $\begin{array}{l}\text { Zapewnienie spójności } \\
\text { społecznej i terytorialnej }\end{array}$ & 12339558,4 & 12210909,4 & 10379273,0 & 10379273,0 \\
\hline Inne projekty & 38987915,1 & 36342215,1 & 21734742,5 & 21734742,5 \\
\hline Ogółem & 116212105,5 & 100685168,5 & 72504842,6 & 72310315,1 \\
\hline
\end{tabular}

Źródło: Jak do tabeli 1.

Na szczególną uwagę zasługują wydatki związane z realizacją projektów w sferze sektora prywatnego. W latach 2010-2013 wartość projektów przedsiębiorstw ogółem wyniosła ponad 546,5 mln zł, jednocześnie wartość dofinansowania unijnego wyniosła w tym czasie 176,5 mln zł. Główną kategorię wydatków stanowiły projekty realizowane na rzecz „Wsparcia dla biznesu (w tym MŚP)” - 342,1 mln zł, przy jednoczesnym planowanym wsparciu ze strony Unii Europejskiej na poziomie 59,7 mln zł. Drugą pozycję stanowiły wydatki w grupie „Badania i wspieranie innowacyjności” $182,4 \mathrm{mln}$ zł, przy planowanym wsparciu na poziomie 102,8 $\mathrm{mln} \mathrm{z}$. Wymienione dwie kategorie łącznie obejmowały 524,4 mln zł, co stanowiło 96,0\% ogółu wydatków zaplanowanych w umowach projektowych w okresie 2010-2013. Z powyższych zestawień wynika zatem, że przedsiębiorstwa sektora prywatnego absorbowały największą ilość środków w ramach wsparcia Unii Europejskiej i niemal w całości kierowały te środki na przedsięwzięcia o charakterze innowacyjnym i ukierunkowane na wspieranie biznesu. Taka struktura wydatków pomiędzy sektorem prywatnym a podmiotami sektor publicznego (powiatowe oraz gminne jednostki samorządu terytorialnego) wydaje się być w pełni uzasadniona i zgodna $\mathrm{z}$ tendencjami zachodzącymi w sektorze publicznym oraz prywatnym w warunkach gospodarki rynkowej. Szczegółowe dane w tym zakresie zamieszczono w tabeli 4. 
Tabela 4. Wydatki podmiotów gospodarczych sektora prywatnego w powiecie lubelskim na rzecz projektów przewodnich realizowanych zgodnie z celami Strategii Europa 2020 (w zl)

\begin{tabular}{|l|c|c|c|c|}
\hline \multicolumn{1}{|c|}{ Wyszczególnienie } & Wartość ogótem & $\begin{array}{c}\text { Wydatki } \\
\text { kwalifikowane }\end{array}$ & Dofinansowanie & $\begin{array}{c}\text { Dofinansowanie } \\
\text { UE }\end{array}$ \\
\hline $\begin{array}{l}\text { Badania i wspieranie } \\
\text { innowacyjności }\end{array}$ & 182359856,6 & 148834937,7 & 70195097,4 & 59665832,6 \\
\hline Poprawa systemów kształcenia & 0,0 & 0,0 & 0,0 & 0,0 \\
\hline $\begin{array}{l}\text { Upowszechnienie internetu } \\
\text { i cyfryzacja }\end{array}$ & 886794,4 & 684499,2 & 394189,6 & 335061,1 \\
\hline $\begin{array}{l}\text { Efektywne wykorzystanie } \\
\text { zasobów }\end{array}$ & 1402476,2 & 1125042,0 & 682909,0 & 580472,6 \\
\hline $\begin{array}{l}\text { Wsparcie dla biznesu } \\
\text { (w tym MŚP) }\end{array}$ & 342059513,0 & 189584169,5 & 119648510,6 & 102814308,6 \\
\hline $\begin{array}{l}\text { Modernizacja rynku pracy, rozwój } \\
\text { umiejętności i zatrudnienie }\end{array}$ & 0,0 & 0,0 & 0,0 & 0,0 \\
\hline $\begin{array}{l}\text { Zapewnienie spójności } \\
\text { społecznej i terytorialnej }\end{array}$ & 0,0 & 0,0 & 0,0 & 0,0 \\
\hline Inne projekty & 19828969,5 & 16055220,8 & 13063784,3 & 13063784,3 \\
\hline Ogółem & 546537609,7 & 356283869,2 & 203984490,8 & 176459459,1 \\
\hline
\end{tabular}

Źródło: Jak do tabeli 1.

Istotnym uzupełnieniem danych empirycznych oraz przeprowadzonej analizy może być ujęcie wydatków na rzecz realizacji projektów współfinansowanych ze środków zewnętrznych w podziale na trzy główne kategorie: wydatki samorządowego podsektora finansów publicznych na poziomie powiatów oraz gmin, a także wydatki podmiotów gospodarczych sektora prywatnego. Dane liczbowe w tym zakresie przedstawiono w tabeli 5 .

Tabela 5. Wydatki unijne ogółem według kategorii beneficjentów w powiecie lubelskim na rzecz projektów przewodnich realizowanych zgodnie z celami Strategii Europa 2020 (w zl)

\begin{tabular}{|l|c|c|c|c|c|c|}
\hline \multicolumn{1}{|c|}{ Wyszczególnienie } & Wartość ogółem & $\begin{array}{c}\text { Struktura (2) } \\
\text { w \% }\end{array}$ & Dofinansowanie & $\begin{array}{c}\text { Dofinansowanie } \\
\text { UE }\end{array}$ & $\begin{array}{c}\text { Struktura } \\
\text { (5) w \% }\end{array}$ & $5 / 2$ \\
\hline 1 & 2 & 3 & 4 & 5 & 6 & 7 \\
\hline Samorząd powiatowy & 141529772,9 & 17,6 & 91085739,1 & 91085739,1 & 26,8 & 64,4 \\
\hline Samorząd gminny & 116212105,5 & 14,4 & 72504842,6 & 72310315,1 & 21,3 & 62,2 \\
\hline $\begin{array}{l}\text { Podmioty gospodarcze } \\
\text { sektora prywatnego }\end{array}$ & 546537609,7 & 68,0 & 203984490,8 & 176459459,1 & 51,9 & 32,3 \\
\hline Ogótem & 804279488,1 & 100,0 & 367575072,5 & 339855513,3 & 100,0 & 42,3 \\
\hline
\end{tabular}

Źródło: Jak do tabeli 1. 
$\mathrm{Z}$ danych tabeli 5 wynika, że podmioty sektora prywatnego absorbowały ponad 2/3 ogółu nakładów skierowanych na realizację przedsięwzięć rozwojowych $(68,0 \%)$ przy jednoczesnym stosunkowo wysokim dofinansowaniu ze strony Unii Europejskiej - ponad 50\%. Wartość projektów przewidzianych do realizacji w ramach struktur samorządu powiatowego stanowiła 17,6\% wartości projektów ogółem, przy jednoczesnej absorpcji 26,8\% wartości dofinansowania ze środków UE kierowanych na realizację zadań w powiecie lubelskim ogółem. W gminnych jednostkach samorządu terytorialnego wartość projektów samorządowych wynosiła zaledwie 14,4\% planowanych wydatków ogółem, przy jednoczesnym stosunkowo niskim udziale w kwocie dofinansowania ze środków UE ogółem (21,3\%). Na rysunku 3 przedstawiono interpretację graficzną omawianych zjawisk.

\section{Rysunek 3. Struktura wydatków ogółem oraz dofinansowanie projektów współfinansowanych ze środków UE w powiecie lubelskim w podziale według głównych grup beneficjentów (w \%)}

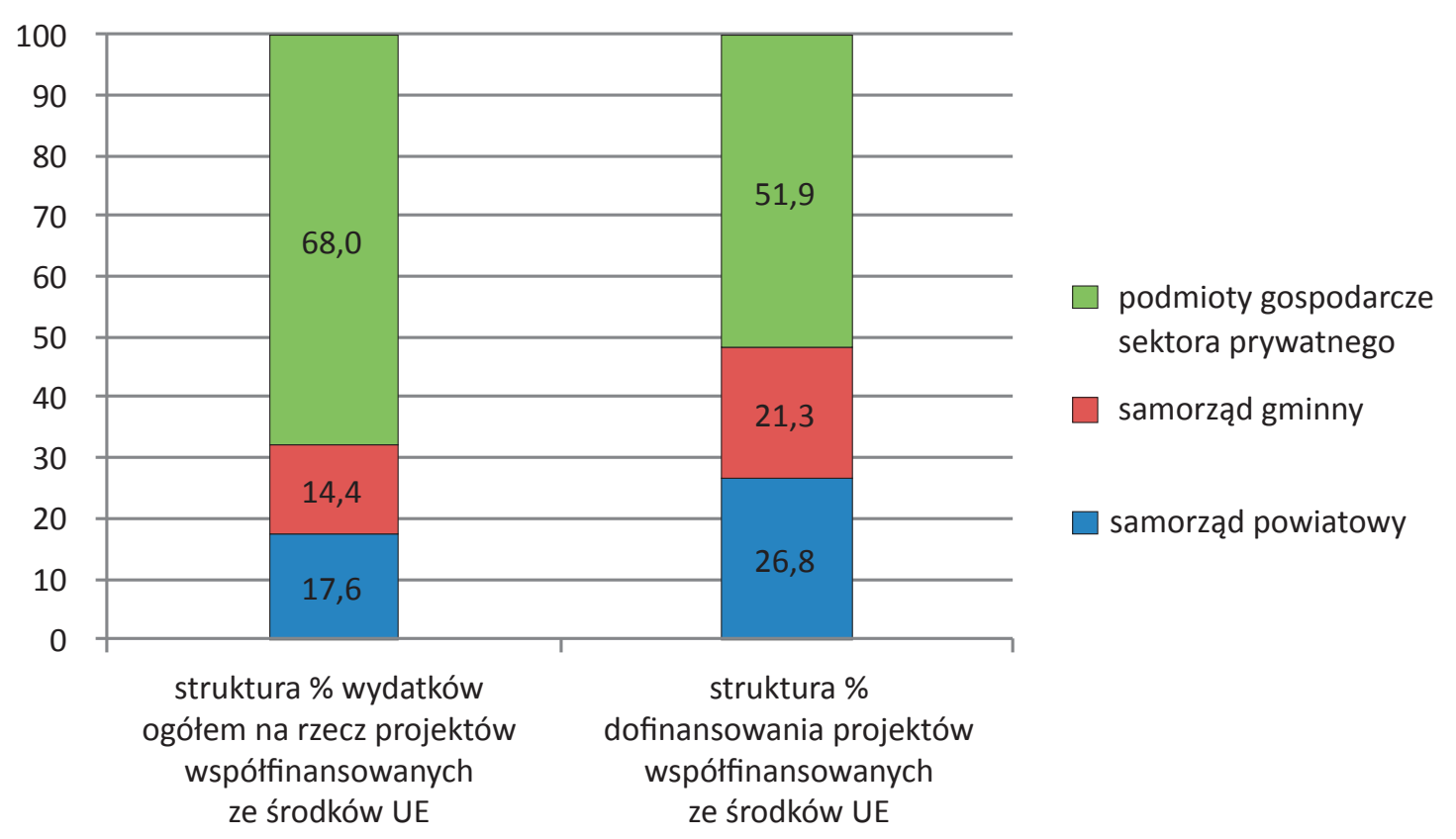

Źródło: Jak do rysunku 1.

Warto również wskazać średni poziom dofinansowania projektów rozwojowych w zakresie powiatowych oraz gminnych jednostek samorządu terytorialnego, a także $\mathrm{w}$ sferze podmiotów sektora prywatnego. W odniesieniu do gmin oraz powiatu lubelskiego średni poziom dofinansowania podjętych przedsięwzięć wynosił od 62,2\% do $64,4 \%$. W sektorze przedsiębiorstw średni poziom dofinansowania projektów wynosił 32,3\%. Dofinansowanie projektów rozwojowych według kategorii beneficjentów przedstawiono na rysunku 4. 
Rysunek 4. Dofinansowanie projektów rozwojowych ogółem ze środków UE w powiecie lubelskim (w \%)

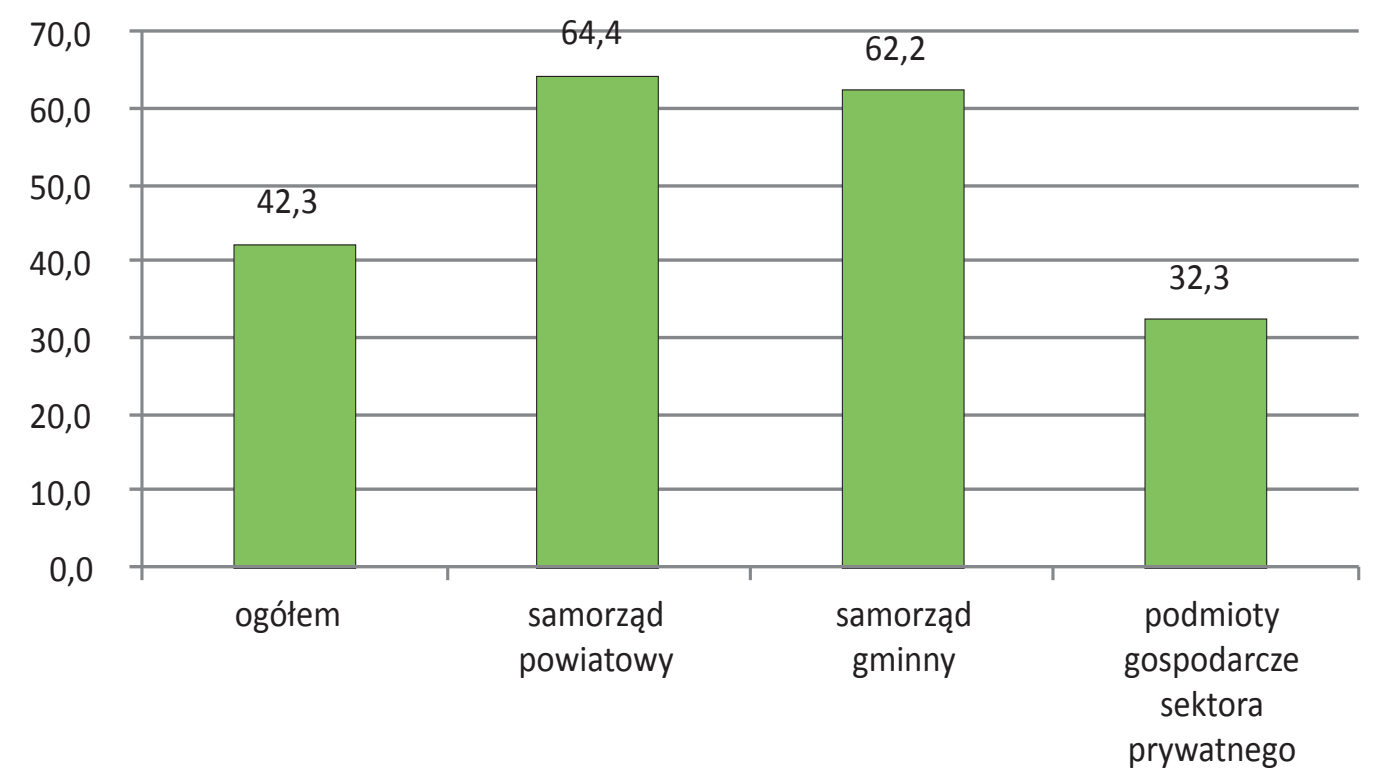

Źródło: Jak do rysunku 1.

W powiecie opolskim wartość projektów ogólem, dla których zawarto umowę lub aneks do umowy, począwszy od roku 2010, wyniosła 890,3 mln zł, z czego dofinansowanie Unii Europejskiej w tym czasie wyniosło 344,6 mln zł. Wśród wymienionych wyżej kategorii najwięcej środków skierowano na realizację przedsięwzięć w zakresie „Efektywnego wykorzystania zasobów”. Na tę kategorię projektów podpisano umowy na łączną kwotę 434,7 mln zł, przy jednoczesnym planowanym dofinansowaniu na poziomie 171,5 mln zł. Drugą znaczącą pozycję stanowiły przedsięwzięcia w sferze „Badań oraz wspierania innowacyjności”. Ogólna wartość zawartych umów w tej kategorii wyniosła nieco powyżej 195,0 mln zł, przy dofinansowaniu ze strony Unii Europejskiej na poziomie 58,7 mln zł. Szczegółowe dane dotyczące wydatków ogólem w powiecie opolskim na realizację projektów zbieżnych z celami Strategii Europa 2020 przedstawiono w tabeli 6. 
Tabela 6. Wydatki ogółem w powiecie opolskim na realizację projektów zbieżnych z celami Strategii Europa 2020 (w zł)

\begin{tabular}{|l|r|r|r|r|}
\hline \multicolumn{1}{|c|}{ Wyszczególnienie } & Wartość ogółem & $\begin{array}{c}\text { Wydatki } \\
\text { kwalifikowane }\end{array}$ & Dofinansowanie & $\begin{array}{c}\text { Dofinansowanie } \\
\text { UE }\end{array}$ \\
\hline $\begin{array}{l}\text { Badania i wspieranie } \\
\text { innowacyjności }\end{array}$ & 195007696,1 & 127020765,9 & 69019153,9 & 58666280,7 \\
\hline Poprawa systemów kształcenia & 7535794,7 & 7374018,6 & 5942568,7 & 5925406,3 \\
\hline $\begin{array}{l}\text { Upowszechnienie internetu } \\
\text { i cyfryzacja }\end{array}$ & 31534467,0 & 25123840,0 & 17749552,6 & 15176346,1 \\
\hline $\begin{array}{l}\text { Efektywne wykorzystanie } \\
\text { zasobów }\end{array}$ & 434715904,3 & 308690766,2 & 171858061,2 & 171479831,3 \\
\hline $\begin{array}{l}\text { Wsparcie dla biznesu } \\
\text { (w tym MŚP) }\end{array}$ & 117832887,8 & 93351901,9 & 45683414,1 & 38883355,1 \\
\hline $\begin{array}{l}\text { Modernizacja rynku pracy, rozwój } \\
\text { umiejętności i zatrudnienie }\end{array}$ & 0,0 & 0,0 & 0,0 & 0,0 \\
\hline $\begin{array}{l}\text { Zapewnienie spójności } \\
\text { społecznej i terytorialnej }\end{array}$ & 15154593,0 & 13042859,2 & 6671351,4 & 5889896,5 \\
\hline Inne projekty & 88568 202,9 & 75839973,8 & 48698024,6 & 48573442,8 \\
\hline Ogółem & 890349545,9 & 650444125,6 & 365622126,5 & 344594558,8 \\
\hline
\end{tabular}

Źródło: Jak do tabeli 1.

Trzecią znaczącą kategorią było „Wsparcie dla biznesu (w tym MŚP)”. W tej grupie projektów na realizację zadań podpisano umowy na łączną kwotę 117,8 $\mathrm{mln}$ zł, przy równoczesnym zapewnieniu zawartego w tej wartości dofinansowania w kwocie 38,9 mln zł. Udział dofinansowania projektów rozwojowych w poszczególnych kategoriach opisujących cele Strategii Europa 2020 przedstawiono graficznie na rysunku 5.

Również w przypadku powiatu opolskiego negatywnym zjawiskiem wydaje się być pominięcie modernizacji rynku pracy oraz rozwoju umiejętności i co za tym idzie oddziaływania na poziom zatrudnienia. W tym samym czasie wartość projektów ogółem związanych z poprawą systemu kształcenia, a także ułatwienia wejścia ludziom młodym na rynek pracy wyniosła 7,5 mln zł, natomiast wartość dofinansowania tych projektów wyniosła $5,9 \mathrm{mln}$ zł. Należy również zwrócić uwagę na projekty związane z cyfryzacją i upowszechnianiem internetu, a także zapewnieniem spójności terytorialnej i społecznej, odpowiednio 31,5 mln zł oraz 15,2 mln zł. Jednocześnie planowana wartość dofinansowania wyniosła odpowiednio $15,2 \mathrm{mln}$ zł oraz 5,9 mln zł. Dofinansowanie ogólem projektów rozwojowych w powiecie opolskim ze środków UE według kategorii celów Strategii Europa 2020 zilustrowano na rysunku 6. 


\section{Rysunek 5. Struktura wydatków w powiecie opolskim według kategorii celów Strategii} Europa 2020 oraz dofinansowanie projektów wspólfinansowanych ze środków UE (w \%)

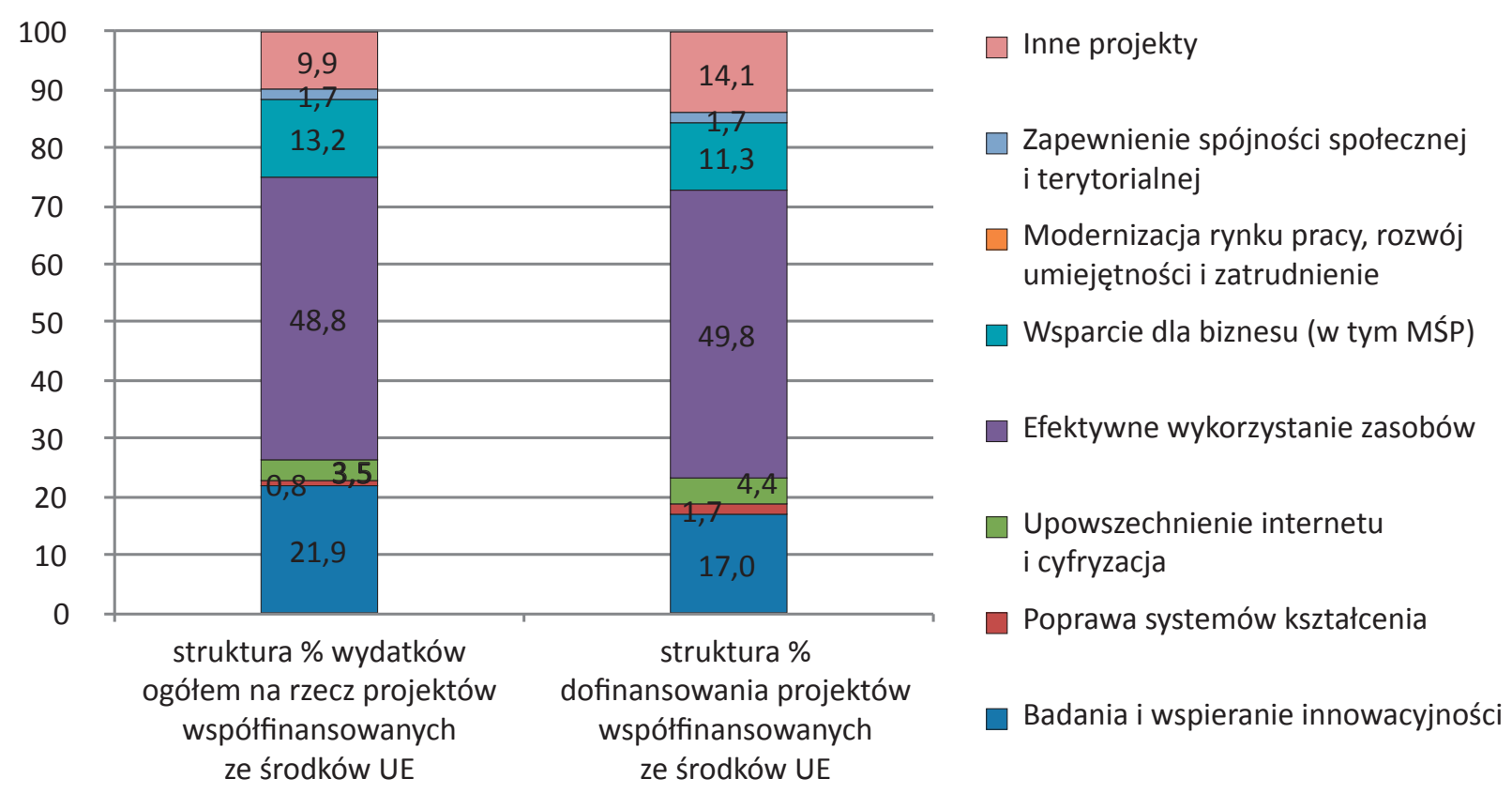

Źródło: Jak do rysunku 1.

Rysunek 6. Dofinansowanie ogółem projektów rozwojowych w powiecie opolskim ze środków UE według kategorii celów Strategii Europa 2020 (w \%)

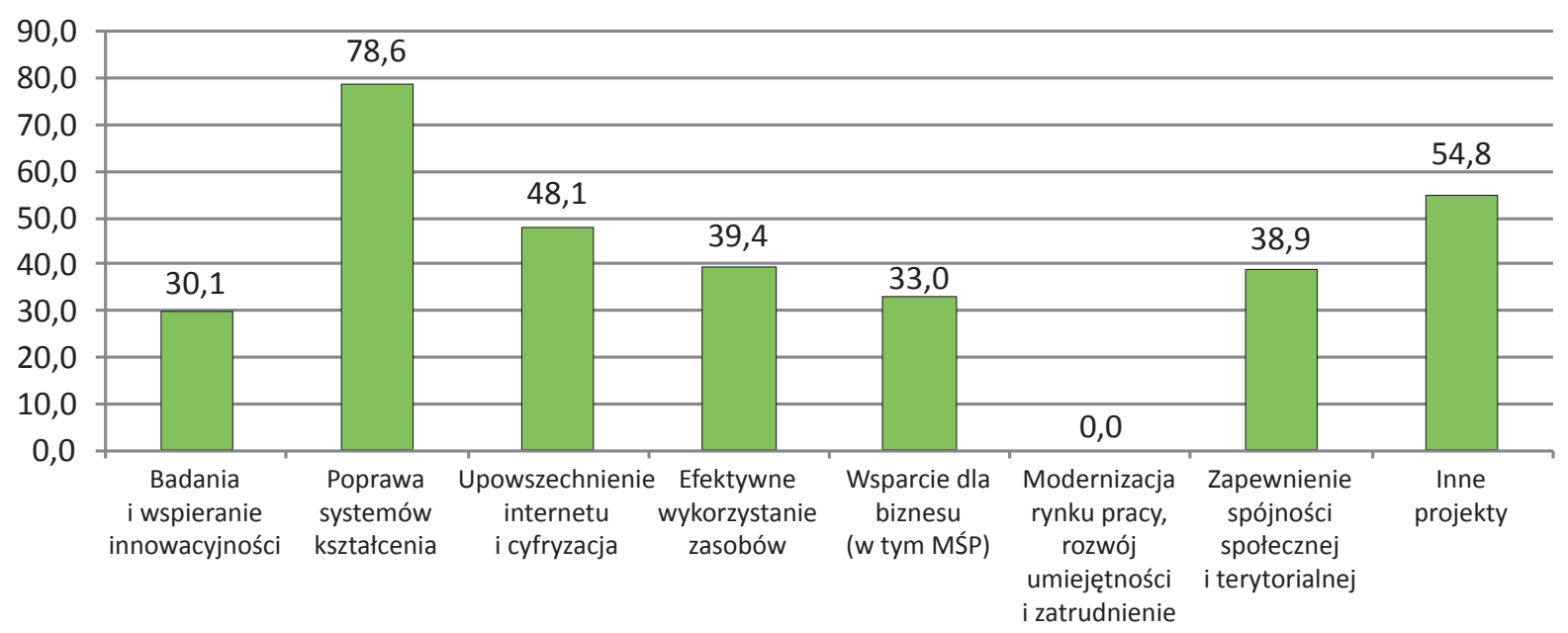

Źródło: Jak do rysunku 1.

Jeśli chodzi o wartość projektów ogółem przewidzianych do realizacji na poziomie samorządu powiatowego, to wyniosła ona 17,3 mln zł, przy jednoczesnym dofinansowaniu na poziomie 11,2 mln zł. Najważniejszą grupą objętą wsparciem było „Efektywne wykorzystanie zasobów”, a zatem podobnie jak w przypadku powiatu 
lubelskiego grupa projektów na rzecz wspierania wzrostu gospodarczego poprzez lepsze wykorzystanie zasobów, w tym zwłaszcza wykorzystanie odnawialnych źródeł energii, modernizację transportu czy też przejście na gospodarkę niskoemisyjną. Drugą co do wartości grupę projektów objętych wsparciem stanowiły „Upowszechnianie internetu i cyfryzacja”. W tym zakresie zawarto umowy na łączną kwotę 266,4 tys. zł, przy czym w kwocie tej wsparcie unijne zostało zaplanowane na poziomie 213,9 tys. zł.

W powiecie opolskim nie realizowano projektów na rzecz „Wsparcia dla biznesu (w tym MŚP)", natomiast dość znaczącą pozycję stanowiły przedsięwzięcia ujęte w badaniu jako kategoria „Inne projekty”. W badanym okresie odnotowano ogólną wartość umów w powyższej kategorii na poziomie 7,1 mln zł, przy dofinansowaniu unijnym $5,2 \mathrm{mln}$ zł. W powiecie opolskim, podobnie jak w powiecie lubelskim, również nie wszystkie projekty skierowane do realizacji i dofinansowywane ze środków unijnych spełniały wymogi celów Strategii Europa 2020. W kategorii „Inne projekty” znalazły się zatem projekty o charakterze infrastrukturalnym głównie w sferze drogownictwa oraz składników infrastruktury, które wchodzą w zakres zadań własnych powiatów. Sytuację w zakresie wydatków unijnych powiatu opolskiego na rzecz projektów przewodnich realizowanych zgodnie z celami Strategii Europa 2020 przedstawiono w tabeli 7.

Tabela 7. Wydatki unijne powiatu opolskiego na rzecz projektów przewodnich realizowanych zgodnie z celami Strategii Europa 2020 (w zł)

\begin{tabular}{|l|c|c|c|c|}
\hline \multicolumn{1}{|c|}{ Wyszczególnienie } & $\begin{array}{c}\text { Wartość } \\
\text { ogótem }\end{array}$ & $\begin{array}{c}\text { Wydatki } \\
\text { kwalifikowane }\end{array}$ & Dofinansowanie & $\begin{array}{c}\text { Dofinansowanie } \\
\text { UE }\end{array}$ \\
\hline Badania i wspieranie innowacyjności & 0,0 & 0,0 & 0,0 & 0,0 \\
\hline Poprawa systemów kształcenia & 0,0 & 0,0 & 0,0 & 0,0 \\
\hline Upowszechnienie internetu i cyfryzacja & 266386,2 & 252626,3 & 213923,9 & 213923,9 \\
\hline Efektywne wykorzystanie zasobów & 10010173,7 & 8946934,3 & 5806494,9 & 5806494,9 \\
\hline Wsparcie dla biznesu (w tym MŚP) & 0,0 & 0,0 & 0,0 & 0,0 \\
\hline $\begin{array}{l}\text { Modernizacja rynku pracy, rozwój } \\
\text { umiejętności i zatrudnienie }\end{array}$ & 0,0 & 0,0 & 0,0 & 0,0 \\
\hline $\begin{array}{l}\text { Zapewnienie spójności społecznej } \\
\text { i terytorialnej }\end{array}$ & 0,0 & 0,0 & 0,0 & 0,0 \\
\hline Inne projekty & 7029763,4 & 6080120,9 & 5168102,8 & 5168102,8 \\
\hline Ogółem & 17306323,3 & 15279681,4 & 11188521,6 & 11188521,6 \\
\hline
\end{tabular}

Źródło: Jak do tabeli 1.

Gminne jednostki samorządu terytorialnego stanowiły w powiecie opolskim bardzo znaczącą grupę podmiotów realizujących projekty objęte dofinansowaniem 
ze środków unijnych. Ogółem na terenie powiatu opolskiego w gminach podpisano umowy na łączną wartość projektów w wysokości powyżej 84,3 mln zł, przy dofinansowaniu w wysokości 54,4 mln zł. Największą wartość projektów odnotowano w grupie „Efektywne wykorzystanie zasobów” - ponad 33,5 mln zł. Drugą co do wielkości grupę projektów zbieżnych z celami Strategii Europa 2020, poza kategorią „Inne projekty”, stanowiły wydatki zaplanowane od roku 2010 na „Zapewnienie spójności społecznej i terytorialnej”. W tej grupie łączne wydatki wyniosły niemal 11,0 mln zł, przy zaplanowanym wsparciu ze strony UE w wysokości 4,3 mln zł. Trzecią grupę projektów zbieżnych z celami Strategii Europa 2020 stanowiła kategoria „Poprawa systemów kształcenia”, a kolejną stanowiły wydatki na „Upowszechnienie internetu i cyfryzację".

Zjawiskiem dość specyficznym był brak wydatków związanych z projektami ujętymi w grupach „Badania i wspieranie innowacyjności” oraz „Modernizacja rynku pracy, rozwój umiejętności i zatrudnienie”. Należy pamiętać, że część celów związanych Z wymienionymi kategoriami przejęły na siebie przedsiębiorstwa prywatne funkcjonujące na terenie gmin powiatu opolskiego. Szczegółowe dane dotyczące wydatków unijnych gmin powiatu opolskiego na rzecz projektów przewodnich realizowanych zgodnie z celami Strategii Europa 2020 przedstawiono w tabeli 8 . W prezentowanym materiale empirycznym przedstawiono również wsparcie realizowanych projektów udzielone z innych źródeł.

Tabela 8. Wydatki unijne gmin powiatu opolskiego na rzecz projektów przewodnich realizowanych zgodnie z celami Strategii Europa 2020 (w zł)

\begin{tabular}{|l|c|c|c|c|}
\hline \multicolumn{1}{|c|}{ Wyszczególnienie } & Wartość ogótem & $\begin{array}{c}\text { Wydatki } \\
\text { kwalifikowane }\end{array}$ & Dofinansowanie & $\begin{array}{c}\text { Dofinansowanie } \\
\text { UE }\end{array}$ \\
\hline $\begin{array}{l}\text { Badania i wspieranie } \\
\text { innowacyjności }\end{array}$ & 0,0 & 0,0 & 0,0 & 0,0 \\
\hline Poprawa systemów kształcenia & 7364577,6 & 7239411,0 & 5828152,3 & 5828152,3 \\
\hline $\begin{array}{l}\text { Upowszechnienie internetu } \\
\text { i cyfryzacja }\end{array}$ & 662072,6 & 662072,6 & 594851,7 & 562761,7 \\
\hline $\begin{array}{l}\text { Efektywne wykorzystanie } \\
\text { zasobów }\end{array}$ & 33507023,6 & 27326854,1 & 20446587,9 & 20446587,9 \\
\hline $\begin{array}{l}\text { Wsparcie dla biznesu } \\
\text { (w tym MŚP) }\end{array}$ & 425884,9 & 411398,6 & 349688,8 & 349688,8 \\
\hline $\begin{array}{l}\text { Modernizacja rynku pracy, rozwój } \\
\text { umiejętności i zatrudnienie }\end{array}$ & 0,0 & 0,0 & 0,0 & 0,0 \\
\hline $\begin{array}{l}\text { Zapewnienie spójności } \\
\text { społecznej i terytorialnej }\end{array}$ & 10961710,0 & 9832926,8 & 4979144,1 & 4262275,1 \\
\hline Inne projekty & 31339611,4 & 28957726,2 & 23107901,7 & 22983320,0 \\
\hline Ogółem & 84260880,2 & 74430389,4 & 55306326,5 & 54432785,8 \\
\hline
\end{tabular}

Źródło: Jak do tabeli 1. 
Ważne miejsce zajmują wydatki związane z finansowaniem projektów w sferze sektora prywatnego. W latach 2010-2013 wartość projektów przedsiębiorstw ogółem wyniosła ponad 788,7 mln zł, przy czym wartość dofinansowania unijnego wyniosła w tym czasie ponad 278,9 mln zł. Główną kategorię wydatków stanowiły projekty realizowane na rzecz „Efektywnego wykorzystania zasobów” - ponad 391,2 mln zł, przy planowanym wsparciu ze strony Unii Europejskiej na poziomie ponad 145,2 mln zł. Drugą pozycję stanowiły wydatki w grupie „Badania i wspieranie innowacyjności” w wysokości ponad 195,0 mln zł, przy planowanym wsparciu unijnym na poziomie ponad 58,7 mln zł. Wymienione dwie kategorie obejmowały łącznie 402,9 $\mathrm{mln} \mathrm{zł}$, co stanowiło 74,3\% ogółu wydatków zaplanowanych w umowach projektowych w okresie 2010-2013. Wydatki unijne podmiotów gospodarczych sektora prywatnego w powiecie opolskim na rzecz projektów przewodnich realizowanych zgodnie z celami Strategii Europa 2020 przedstawiono w tabeli 9.

Tabela 9. Wydatki unijne podmiotów gospodarczych sektora prywatnego w powiecie opolskim na rzecz projektów przewodnich realizowanych zgodnie z celami Strategii Europa 2020 (w zl)

\begin{tabular}{|l|r|r|r|r|}
\hline \multicolumn{1}{|c|}{ Wyszczególnienie } & Wartość ogółem & $\begin{array}{c}\text { Wydatki } \\
\text { kwalifikowane }\end{array}$ & Dofinansowanie & $\begin{array}{c}\text { Dofinansowanie } \\
\text { UE }\end{array}$ \\
\hline $\begin{array}{l}\text { Badania i wspieranie } \\
\text { innowacyjności }\end{array}$ & 195007696,1 & 127020765,9 & 69019153,9 & 58666280,7 \\
\hline Poprawa systemów kształcenia & 171217,1 & 134607,6 & 114416,4 & 97254,0 \\
\hline $\begin{array}{l}\text { Upowszechnienie internetu } \\
\text { i cyfryzacja }\end{array}$ & 30606008,1 & 24209141,1 & 16940777,0 & 14399660,4 \\
\hline $\begin{array}{l}\text { Efektywne wykorzystanie } \\
\text { zasobów }\end{array}$ & 391198707,0 & 272416977,8 & 145604978,4 & 145226748,5 \\
\hline $\begin{array}{l}\text { Wsparcie dla biznesu } \\
\text { (w tym MŚP) }\end{array}$ & 117407002,9 & 92940503,3 & 45333725,2 & 38533666,3 \\
\hline $\begin{array}{l}\text { Modernizacja rynku pracy, rozwój } \\
\text { umiejętności i zatrudnienie }\end{array}$ & 0,0 & 0,0 & 0,0 & 0,0 \\
\hline $\begin{array}{l}\text { Zapewnienie spójności } \\
\text { społecznej i terytorialnej }\end{array}$ & 4192883,0 & 3209932,4 & 1692207,4 & 1627621,3 \\
\hline Inne projekty & 50198828,1 & 40802126,6 & 20422020,1 & 20422020,1 \\
\hline Ogółem & 78878342,4 & 560734054,8 & 299127278,4 & 278973251,3 \\
\hline
\end{tabular}

Źródło: Jak do tabeli 1.

Z prezentowanych zestawień wynika, że przedsiębiorstwa sektora prywatnego absorbowały największą ilość środków w ramach wsparcia Unii Europejskiej i niemal w całości kierowały te środki na przedsięwzięcia o charakterze innowacyjnym i ukierunkowane na wspieranie biznesu. Podmioty te absorbowały ponad 4/5 ogółu nakładów skierowanych na realizację przedsięwzięć rozwojowych (88,0\%), przy 
jednoczesnym wysokim dofinansowaniu ogółem ze strony Unii Europejskiej - nieco ponad $80,0 \%$ kwoty dofinansowania w powiecie ogółem. Taka struktura wydatków w powiecie opolskim pomiędzy sektorem prywatnym a podmiotami sektora publicznego (powiatowe oraz gminne jednostki samorządu terytorialnego) wydaje się również być $\mathrm{w}$ pełni uzasadniona i zgodna $\mathrm{z}$ tendencjami zachodzącymi w sektorze publicznym oraz prywatnym w warunkach gospodarki rynkowej. Zestawienie wyników oraz ilustrację graficzną przedstawiono w tabeli 10 oraz na rysunku 7.

Tabela 10. Wydatki unijne ogółem według kategorii beneficjentów w powiecie opolskim na rzecz projektów przewodnich realizowanych zgodnie z celami Strategii Europa 2020 (w zl)

\begin{tabular}{|l|c|c|c|c|}
\hline \multicolumn{1}{|c|}{ Wyszczególnienie } & Wartość ogófem & $\begin{array}{c}\text { Wydatki } \\
\text { kwalifikowane }\end{array}$ & Dofinansowanie & $\begin{array}{c}\text { Dofinansowanie } \\
\text { UE }\end{array}$ \\
\hline Samorząd powiatowy & 17306323,3 & 15279681,4 & 11188521,6 & 11188521,6 \\
\hline Samorząd gminny & 84260880,2 & 74430389,4 & 55306326,5 & 54432785,8 \\
\hline $\begin{array}{l}\text { Podmioty gospodarcze sektora } \\
\text { prywatnego }\end{array}$ & 788782342,4 & 560734054,8 & 299127278,4 & 278973251,3 \\
\hline Ogółem & 890349545,9 & 650444125,6 & 365622126,5 & 344594558,8 \\
\hline
\end{tabular}

Źródło: Jak do tabeli 1.

Rysunek 7. Struktura wydatków ogółem oraz dofinansowanie projektów współfinansowanych ze środków UE w powiecie opolskim w podziale według głównych grup beneficjentów (w \%)

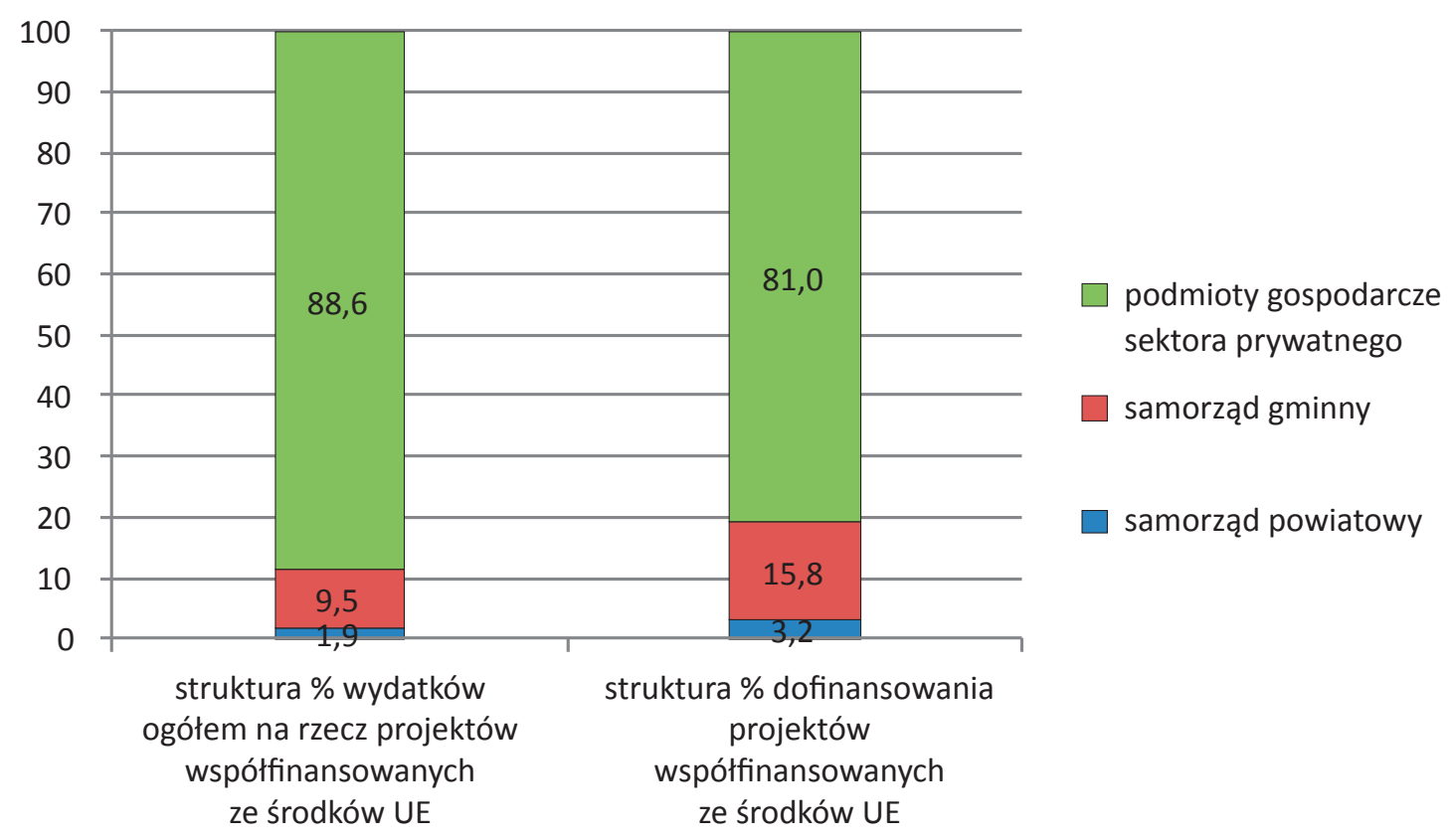

Źródło: Jak do rysunku 1. 
Wartość projektów przewidzianych do realizacji w ramach struktur samorządu powiatowego stanowiła 1,9\% wartości projektów ogółem, przy jednoczesnej absorpcji 3,2\% wartości dofinansowania ze środków UE, kierowanych na realizację zadań w powiecie opolskim ogółem. W gminnych jednostkach samorządu terytorialnego wartość projektów samorządowych wynosiła zaledwie 9,5\% planowanych wydatków ogółem, przy jednoczesnym stosunkowo niskim udziale w kwocie dofinansowania ze środków UE ogółem (15,8\%).

Warto również zwrócić uwagę na średni poziom dofinansowania projektów rozwojowych w zakresie powiatowych oraz gminnych jednostek samorządu terytorialnego, a także w sferze podmiotów sektora prywatnego. W odniesieniu do gmin oraz powiatu opolskiego średni poziom dofinansowania podjętych przedsięwzięć wynosił $64,6 \%$. W sektorze przedsiębiorstw średni poziom dofinansowania projektów wynosił $35,4 \%$. Dofinansowanie projektów rozwojowych według kategorii beneficjentów przedstawiono na rysunku 8.

Rysunek 8. Dofinansowanie projektów rozwojowych ogółem ze środków UE w powiecie opolskim (w \%)

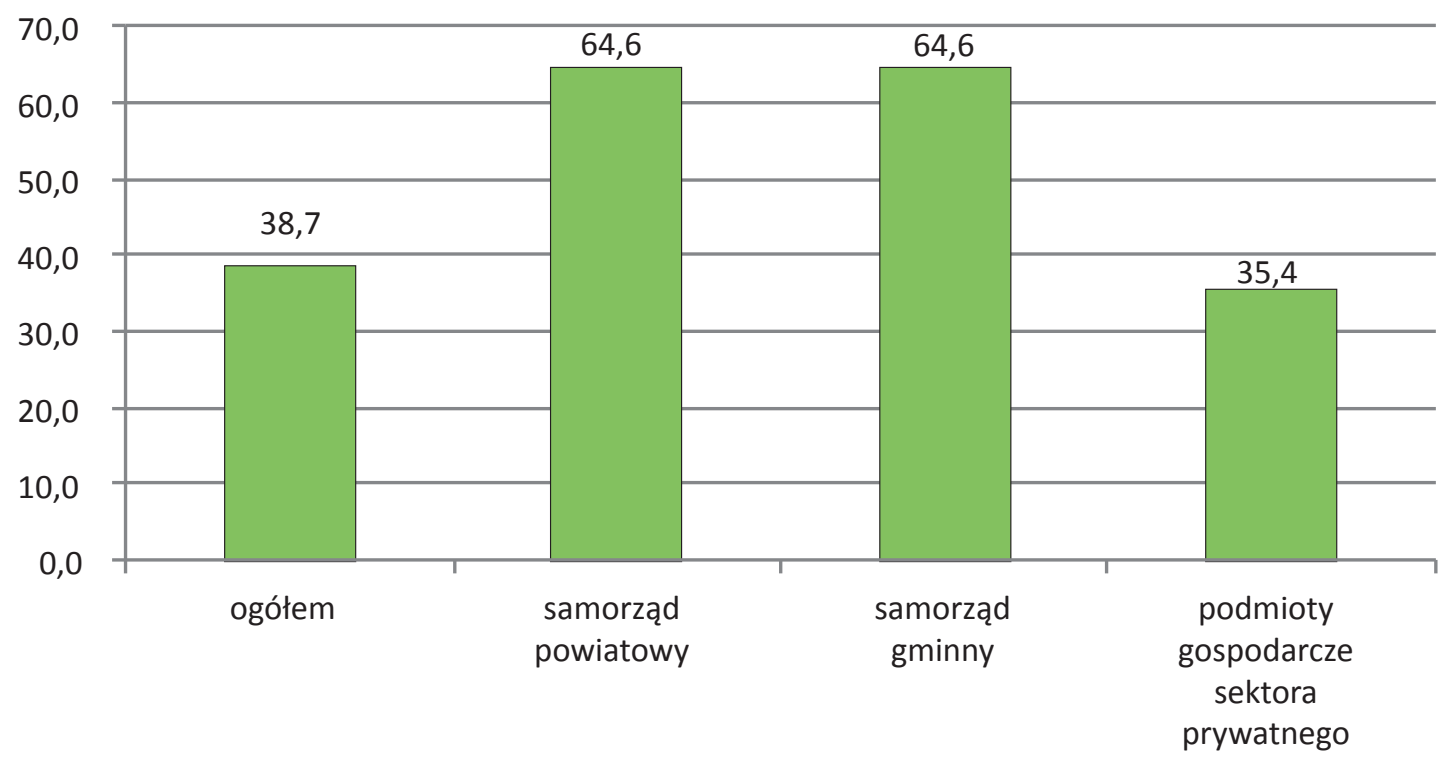

Źródło: Jak do rysunku 1.

W powiecie wejherowskim wartość projektów ogółem, dla których zawarto umowę lub aneks do umowy, począwszy od roku 2010, wyniosła ponad 386,7 mln zł, z czego dofinansowanie Unii Europejskiej w tym czasie wyniosło 170,7 mln zł. Wśród analizowanych kategorii najwięcej środków skierowano na realizację przedsięwzięć 
w zakresie „Efektywnego wykorzystania zasobów”. Na tę kategorię projektów podpisano umowy na łączną kwotę ponad 81,4 mln zł, przy jednoczesnym planowanym dofinansowaniu na poziomie $35,1 \mathrm{mln}$ zł. Drugą znaczącą pozycję stanowiły przedsięwzięcia w sferze „Badań oraz wspierania innowacyjności”. Ogólna wartość zawartych umów w tej kategorii wyniosła nieco powyżej 57,6 mln zł, przy dofinansowaniu ze strony Unii Europejskiej na poziomie 24,1 mln zł. Należy także wyróżnić wydatki na rzecz „Poprawy systemów kształcenia” oraz „Upowszechnienia internetu i cyfryzacji”. W tych dwóch grupach wydatki zaplanowano odpowiednio na poziomie 25,4 mln zł oraz 21,1 mln zł, przy dofinansowaniu odpowiednio 7,6 $\mathrm{mln}$ zł i 3,5 mln zł. Szczegółowe dane przedstawiono w tabeli 11. Dofinansowania projektów rozwojowych w poszczególnych kategoriach opisujących cele Strategii Europa 2020 przedstawiono graficznie na rysunkach 9 oraz 10.

Tabela 11. Wydatki unijne ogółem w powiecie wejherowskim na rzecz projektów przewodnich realizowanych zgodnie z celami Strategii Europa 2020 (w zl)

\begin{tabular}{|l|c|r|r|r|}
\hline \multicolumn{1}{|c|}{ Wyszczególnienie } & $\begin{array}{c}\text { Wartość } \\
\text { ogótem }\end{array}$ & $\begin{array}{c}\text { Wydatki } \\
\text { kwalifikowane }\end{array}$ & Dofinansowanie & $\begin{array}{c}\text { Dofinansowanie } \\
\text { UE }\end{array}$ \\
\hline $\begin{array}{l}\text { Badania i wspieranie } \\
\text { innowacyjności }\end{array}$ & 57605983,2 & 53529177,0 & 27986378,5 & 24147375,8 \\
\hline Poprawa systemów kształcenia & 25444704,8 & 23710607,3 & 7551288,9 & 7551288,9 \\
\hline $\begin{array}{l}\text { Upowszechnienie internetu } \\
\text { i cyfryzacja }\end{array}$ & 21091433,6 & 18426850,0 & 12535699,4 & 11093498,2 \\
\hline $\begin{array}{l}\text { Efektywne wykorzystanie } \\
\text { zasobów }\end{array}$ & 81365405,1 & 59283681,4 & 35830672,9 & 35132302,6 \\
\hline $\begin{array}{l}\text { Wsparcie dla biznesu } \\
\text { (w tym MŚSP) }\end{array}$ & 15664815,6 & 12763459,2 & 7772199,7 & 7326443,5 \\
\hline $\begin{array}{l}\text { Modernizacja rynku pracy, rozwój } \\
\text { umiejętności i zatrudnienie }\end{array}$ & 0,0 & 0,0 & 0,0 & 0,0 \\
\hline $\begin{array}{l}\text { Zapewnienie spójności } \\
\text { społecznej i terytorialnej }\end{array}$ & 48430865,8 & 45864021,0 & 27943573,9 & 27943573,9 \\
\hline Inne projekty & 137053449,4 & 120030672,5 & 58977202,4 & 57535531,4 \\
\hline Ogółem & 386656657,4 & 333608468,3 & 178597015,7 & 170730014,2 \\
\hline
\end{tabular}

Źródło: Jak do tabeli 1. 
Rysunek 9. Struktura wydatków w powiecie wejherowskim według kategorii celów Strategii Europa 2020 oraz dofinansowanie projektów współfinansowanych ze środków UE (w \%)

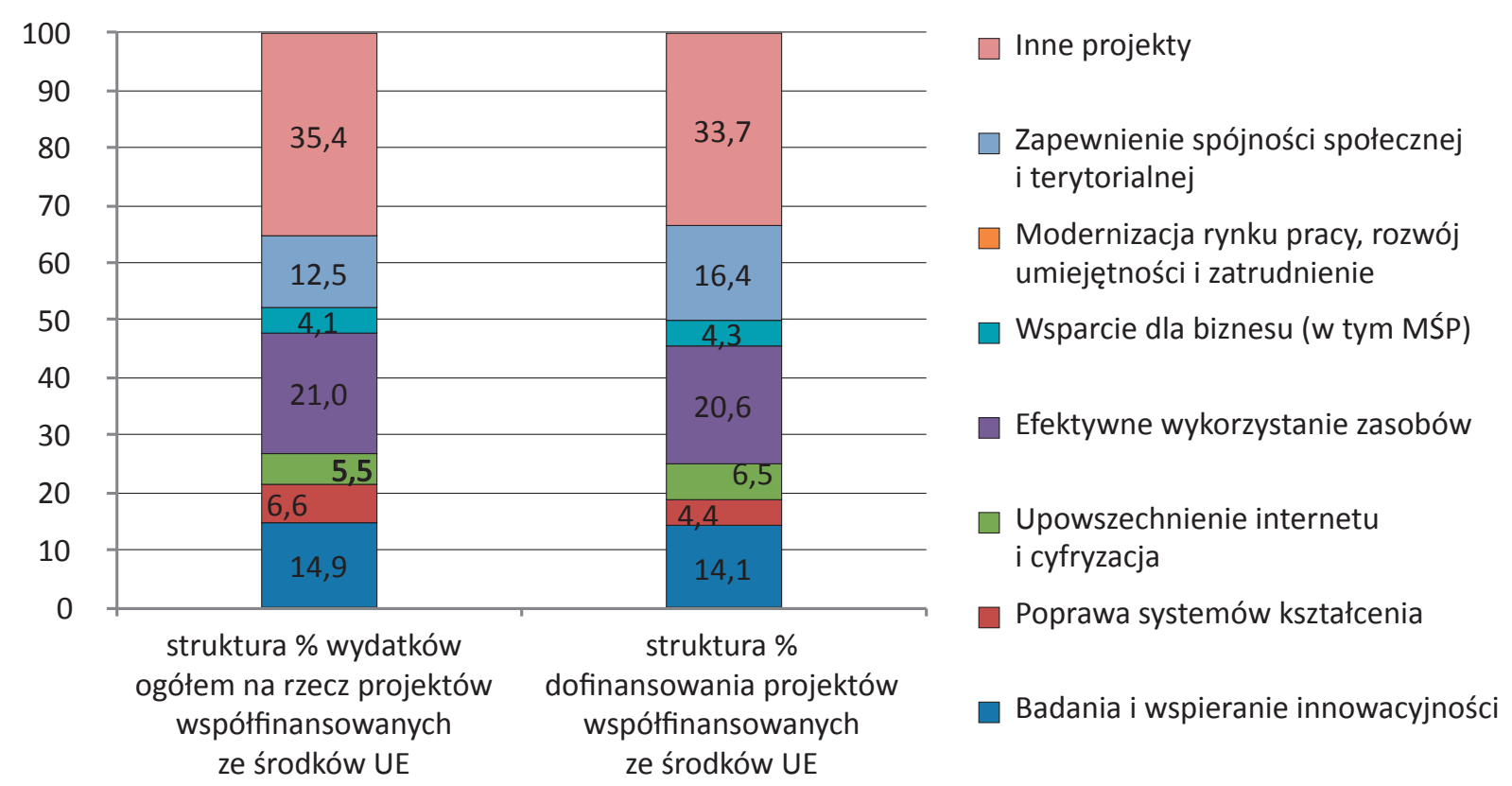

Źródło: Jak do rysunku 1.

Rysunek 10. Dofinansowanie ogółem projektów rozwojowych w powiecie wejherowskim ze środków UE według kategorii celów Strategii Europa 2020 (w \%)

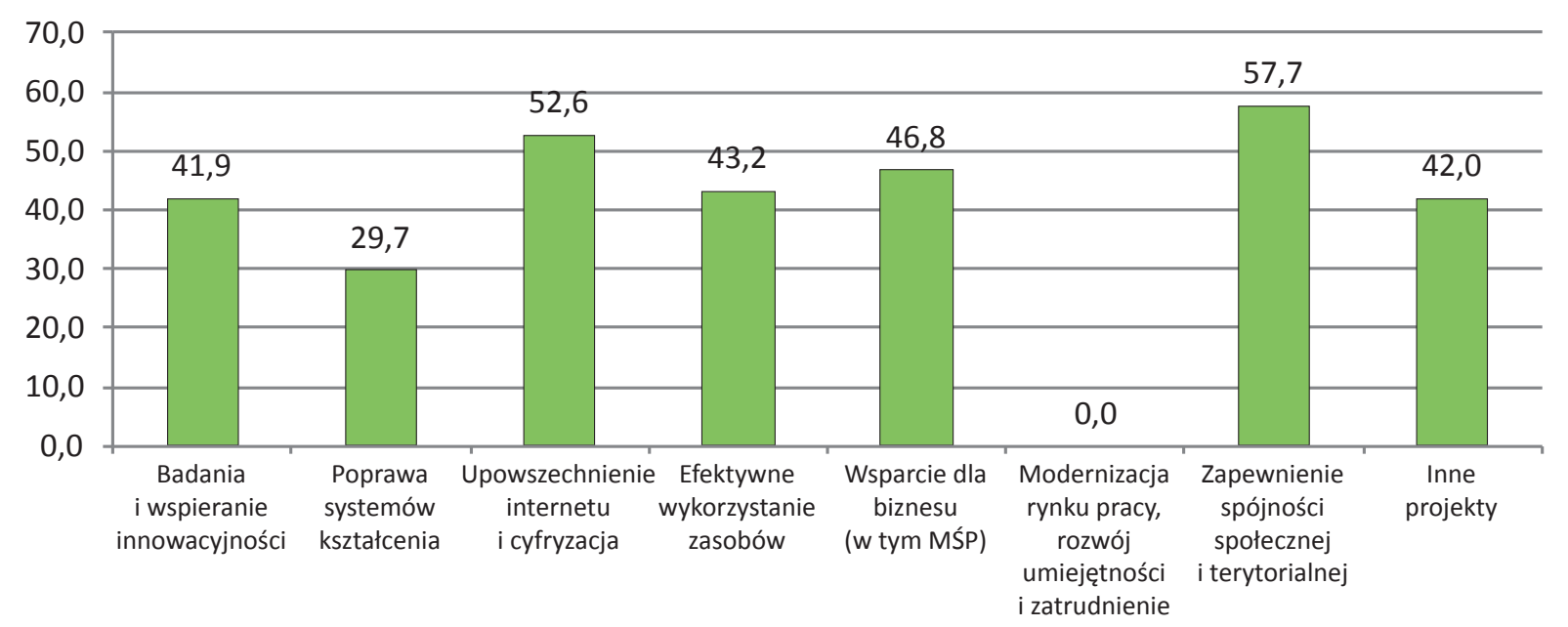

Źródło: Jak do rysunku 1.

Wartość projektów ogółem przewidzianych do realizacji na poziomie samorządu powiatowego wyniosła ponad 70,0 mln zł, przy jednoczesnym dofinansowaniu na poziomie 45,0 mln zł. Szczegółowe dane dotyczące sytuacji w zakresie finansowania projektów na poziomie samorządu powiatowego przedstawiono w tabeli 12 . 
Najważniejszą grupą objętą wsparciem były przedsięwzięcia z kategorii „Inne projekty", gdzie łączna wartość projektów wyniosła 63,2 mln zł, przy dofinansowaniu 39,6 mln zł. Drugą co do wartości grupę projektów objętych wsparciem stanowiło „Upowszechnienie internetu i cyfryzacja”. Na tę grupę projektów zawarto umowy na łączną kwotę 3,9 mln zł, przy czym w kwocie tej wsparcie unijne zostało zaplanowane na poziomie $2,9 \mathrm{mln}$ zł. Trzecią co do wartości grupę projektów objętych wsparciem stanowiło „Zapewnienie spójności społecznej i terytorialnej”. Na tę grupę projektów zawarto umowy na łączną kwotę 2,9 mln zł, przy czym wsparcie unijne zostało zaplanowane na poziomie $2,5 \mathrm{mln}$ zł. W powiecie wejherowskim w pozostałych kategoriach projektów nie zaplanowano wydatków.

Tabela 12. Wydatki unijne powiatu wejherowskiego na rzecz projektów przewodnich realizowanych zgodnie z celami Strategii Europa 2020 (w zl)

\begin{tabular}{|l|c|c|c|c|}
\hline \multicolumn{1}{|c|}{ Wyszczególnienie } & Wartość ogótem & $\begin{array}{c}\text { Wydatki } \\
\text { kwalifikowane }\end{array}$ & Dofinansowanie & $\begin{array}{c}\text { Dofinansowanie } \\
\text { UE }\end{array}$ \\
\hline Badania i wspieranie innowacyjności & 0,0 & 0,0 & 0,0 & 0,0 \\
\hline Poprawa systemów kształcenia & 0,0 & 0,0 & 0,0 & 0,0 \\
\hline $\begin{array}{l}\text { Upowszechnienie internetu } \\
\text { i cyfryzacja }\end{array}$ & 3907000,0 & 3894700,0 & 2921025,0 & 2921025,0 \\
\hline Efektywne wykorzystanie zasobów & 0,0 & 0,0 & 0,0 & 0,0 \\
\hline Wsparcie dla biznesu (w tym MŚP) & 0,0 & 0,0 & 0,0 & 0,0 \\
\hline $\begin{array}{l}\text { Modernizacja rynku pracy, rozwój } \\
\text { umiejętności i zatrudnienie }\end{array}$ & 0,0 & 0,0 & 0,0 & 0,0 \\
\hline $\begin{array}{l}\text { Zapewnienie spójności społecznej } \\
\text { i terytorialnej }\end{array}$ & 2946000,0 & 2946000,0 & 2504100,0 & 2504100,0 \\
\hline Inne projekty & 63169736,8 & 59228348,9 & 39585388,6 & 39585388,6 \\
\hline Ogółem & 70022736,8 & 66069048,9 & 45010513,6 & 45010513,6 \\
\hline
\end{tabular}

Źródło: Jak do tabeli 1.

Gminne jednostki samorządu terytorialnego stanowiły w powiecie wejherowskim ważną grupę podmiotów realizujących projekty objęte dofinansowaniem ze środków UE. Ogółem na terenie powiatu wejherowskiego w gminach podpisano umowy na łączną wartość projektów w wysokości powyżej 223,4 mln zł, przy dofinansowaniu w wysokości 88,6 mln zł. Największą wartość projektów odnotowano w grupie „Efektywne wykorzystanie zasobów” - ponad 75,4 mln zł. Drugą co do wielkości grupę projektów zbieżnych z celami Strategii Europa 2020, poza kategorią „Inne projekty”, stanowiły wydatki zaplanowane od roku 2010 na „Zapewnienie spójności społecznej i terytorialnej”. W tej grupie łączne zaplanowane wydatki wyniosły

7 K. Jarosiński, B. Opałka, op.cit., s. 46. 
niemal 41,1 mln zł, przy zaplanowanym wsparciu ze strony UE w wysokości ponad 23,8 mln zł. Trzecią grupę projektów zbieżnych z celami Strategii Europa 2020 stanowiła kategoria „Poprawa systemów kształcenia”, a kolejną stanowiły wydatki na „Wsparcie dla biznesu (w tym MŚP)”.

W gminach powiatu wejherowskiego nie podjęto wydatków związanych z projektami ujętymi w grupach „Badania i wspieranie innowacyjności” oraz „Modernizacja rynku pracy, rozwój umiejętności i zatrudnienie”. Szczegółowe dane dotyczące wydatków unijnych gmin powiatu wejherowskiego na rzecz projektów przewodnich realizowanych zgodnie z celami Strategii Europa 2020 przedstawiono w tabeli 13.

Tabela 13. Wydatki unijne gmin powiatu wejherowskiego na rzecz projektów przewodnich realizowanych zgodnie z celami Strategii Europa 2020 (w zl)

\begin{tabular}{|l|c|c|c|c|}
\hline \multicolumn{1}{|c|}{ Wyszczególnienie } & Wartość ogótem & $\begin{array}{c}\text { Wydatki } \\
\text { kwalifikowane }\end{array}$ & Dofinansowanie & $\begin{array}{c}\text { Dofinansowanie } \\
\text { UE }\end{array}$ \\
\hline $\begin{array}{l}\text { Badania i wspieranie } \\
\text { innowacyjnósci }\end{array}$ & 0,0 & 0,0 & 0,0 & 0,0 \\
\hline Poprawa systemów kształcenia & 25444704,8 & 23710607,3 & 7551288,9 & 7551288,9 \\
\hline $\begin{array}{l}\text { Upowszechnienie internetu } \\
\text { i cyfryzacja }\end{array}$ & 3000482,4 & 3000482,4 & 3000482,4 & 2550410,0 \\
\hline $\begin{array}{l}\text { Efektywne wykorzystanie } \\
\text { zasobów }\end{array}$ & 75452078,0 & 54518852,4 & 34285812,3 & 33587442,0 \\
\hline $\begin{array}{l}\text { Wsparcie dla biznesu } \\
\text { (w tym MŚP) }\end{array}$ & 4516210,1 & 3650087,1 & 3093726,8 & 3093726,8 \\
\hline $\begin{array}{l}\text { Modernizacja rynku pracy, rozwój } \\
\text { umiejętności i zatrudnienie }\end{array}$ & 0,0 & 0,0 & 0,0 & 0,0 \\
\hline $\begin{array}{l}\text { Zapewnienie spójności } \\
\text { społecznej i terytorialnej }\end{array}$ & 41088184,8 & 39165423,7 & 23834958,9 & 23834958,9 \\
\hline Inne projekty & 73883712,6 & 60802323,6 & 19391813,8 & 17950142,8 \\
\hline Ogółem & 223385372,6 & 184847776,5 & 91158083,1 & 88567969,4 \\
\hline
\end{tabular}

Źródło: Jak do tabeli 1.

Znaczące miejsce zajmują wydatki związane z finansowaniem projektów w sektorze prywatnym. W latach 2010-2013 wartość projektów przedsiębiorstw ogółem wyniosła ponad 93,2 mln zł, przy dofinansowaniu unijnym ponad 37,1 mln zł. Główną kategorię wydatków stanowiły projekty realizowane w grupie „Badania i wspieranie innowacyjności” - ponad 57,0 mln zł, przy planowanym wsparciu ze strony Unii Europejskiej na poziomie ponad $24,1 \mathrm{mln}$ zł. Drugą pozycję stanowiły wydatki w grupie „Upowszechnienie internetu i cyfryzacja” w wysokości ponad 14,1 mln zł, przy planowanym wsparciu unijnym na poziomie ponad 5,6 mln zł. Wymienione dwie kategorie obejmowały łącznie ponad 71,7 mln zł, co stanowiło 76,9\% ogółu wydatków zaplanowanych w latach 2010-2013. 
Tabela 14. Wydatki unijne podmiotów gospodarczych sektora prywatnego $\mathrm{w}$ powiecie wejherowskim na rzecz projektów przewodnich realizowanych zgodnie z celami Strategii Europa 2020 (w zl)

\begin{tabular}{|l|c|c|c|c|}
\hline \multicolumn{1}{|c|}{ Wyszczególnienie } & $\begin{array}{c}\text { Wartość } \\
\text { ogółem }\end{array}$ & $\begin{array}{c}\text { Wydatki } \\
\text { kwalifikowane }\end{array}$ & Dofinansowanie & $\begin{array}{c}\text { Dofinansowanie } \\
\text { UE }\end{array}$ \\
\hline Badania i wspieranie innowacyjności & 57605983,2 & 53529177,0 & 27986378,5 & 24147375,8 \\
\hline Poprawa systemów kształcenia & 0,0 & 0,0 & 0,0 & 0,0 \\
\hline Upowszechnienie internetu i cyfryzacja & 14183951,2 & 11531667,6 & 6614192,0 & 5622063,2 \\
\hline Efektywne wykorzystanie zasobów & 5913327,2 & 4764828,9 & 1544860,6 & 1544860,6 \\
\hline Wsparcie dla biznesu (w tym MŚP) & 11148605,6 & 9113372,1 & 4678472,9 & 4232716,7 \\
\hline $\begin{array}{l}\text { Modernizacja rynku pracy, rozwój } \\
\text { umiejętności i zatrudnienie }\end{array}$ & 0,0 & 0,0 & 0,0 & 0,0 \\
\hline $\begin{array}{l}\text { Zapewnienie spójności społecznej } \\
\text { i terytorialnej }\end{array}$ & 4396680,9 & 3752597,3 & 1604515,0 & 1604515,0 \\
\hline Inne projekty & 0,0 & 0,0 & 0,0 & 0,0 \\
\hline Ogótem & 93248548,0 & 82691642,9 & 42428419,0 & 37151531,2 \\
\hline
\end{tabular}

Źródło: Jak do tabeli 1.

Wyniki badań wskazują, że największą ilość środków w ramach wsparcia Unii Europejskiej absorbowały gminne jednostki samorządowe, które głównie kierowały te środki na realizację zadań własnych. Przedsiębiorstwa sektora prywatnego absorbowały jedynie około $1 / 4$ ogółu środków przeznaczonych na realizację projektów. Taka struktura wydatków w powiecie wejherowskim wskazuje na nieco inną orientację alokacji zasobów niż w przypadku wcześniej omówionych powiatów lubelskiego oraz opolskiego. Sytuacja taka wynika zapewne $\mathrm{z}$ większych potrzeb, jeśli chodzi o infrastrukturę techniczną oraz społeczną, przy jednoczesnym silnym ciążeniu w kierunku aglomeracji gdańskiej, co może stanowić poważne ograniczenie w rozwoju biznesu na terenie powiatu. Dane ilustrujące wydatki unijne ogółem według kategorii beneficjentów w powiecie wejherowskim na rzecz projektów przewodnich realizowanych zgodnie z celami Strategii Europa 2020 przedstawiono w tabeli 15 oraz na rysunku 11.

Tabela 15. Wydatki unijne ogółem według kategorii beneficjentów w powiecie wejherowskim na rzecz projektów przewodnich realizowanych zgodnie z celami Strategii Europa 2020 (w zł)

\begin{tabular}{|l|r|r|r|r|}
\hline \multicolumn{1}{|c|}{ Wyszczególnienie } & Wartość ogótem & \multicolumn{1}{c|}{$\begin{array}{c}\text { Wydatki } \\
\text { kwalifikowane }\end{array}$} & Dofinansowanie & $\begin{array}{c}\text { Dofinansowanie } \\
\text { UE }\end{array}$ \\
\hline Samorząd powiatowy & 70022736,8 & 66069048,9 & 45010513,6 & 45010513,6 \\
\hline Samorząd gminny & 223385372,6 & 184847776,5 & 91158083,1 & 88567969,4 \\
\hline Podmioty gospodarcze sektora prywatnego & 93248548,0 & 82691642,9 & 42428419,0 & 37151531,2 \\
\hline Ogótem & 386656657,4 & 333608468,3 & 178597015,7 & 170730014,2 \\
\hline
\end{tabular}

Źródło: Jak do tabeli 1. 
Rysunek 11. Struktura wydatków ogółem oraz dofinansowanie projektów współfinansowanych ze środków UE w powiecie wejherowskim w podziale według głównych grup beneficjentów (w \%)

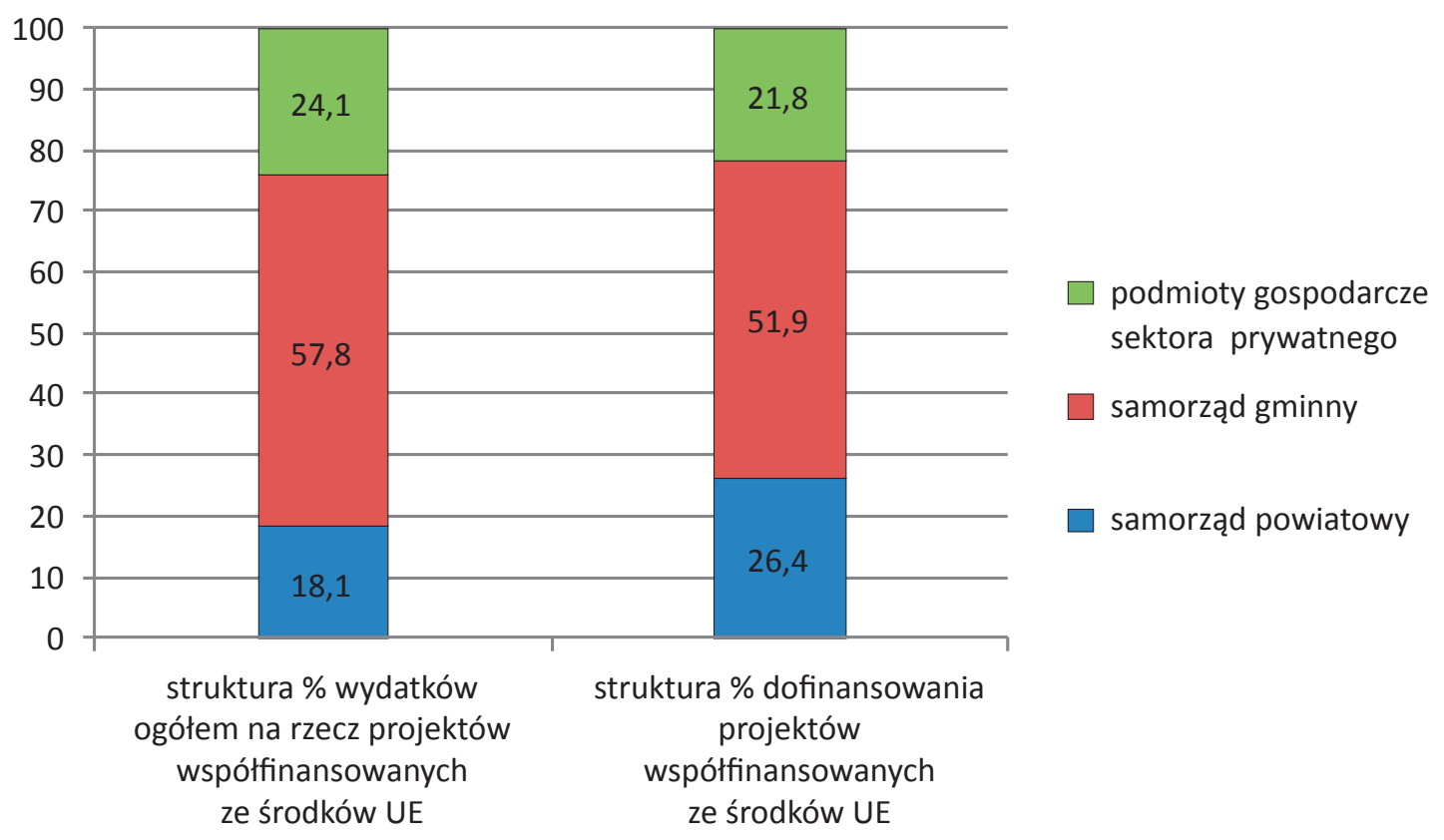

Źródło: Jak do rysunku 1.

Z rysunku 11 wynika, że podmioty sektora prywatnego absorbowały 24,1\% ogółu nakładów skierowanych na realizację przedsięwzięć rozwojowych, przy jednoczesnym dofinansowaniu ogółem ze strony Unii Europejskiej niemal 22\% kwoty dofinansowania w powiecie ogólem. Wartość projektów przewidzianych do realizacji w ramach struktur samorządu powiatowego stanowiła 18,1\% wartości projektów ogółem, przy jednoczesnej absorpcji 26,4\% wartości dofinansowania ze środków UE, kierowanych na realizację zadań w powiecie wejherowskim ogółem. Największy udział w kwocie planowanych wydatków ogółem uzyskały gminne jednostki samorządu terytorialnego, gdzie wartość projektów samorządowych wynosiła 57,8\%, przy jednoczesnym równie wysokim udziale w dofinansowania ze środków UE ogółem (51,9\%).

Warto też zwrócić uwagę na średni poziom dofinansowania projektów rozwojowych w zakresie powiatowych oraz gminnych jednostek samorządu terytorialnego i w sferze podmiotów sektora prywatnego. W odniesieniu do gmin oraz powiatu wejherowskiego średni poziom dofinansowania podjętych przedsięwzięć wynosił odpowiednio $39,6 \%$ i $64,3 \%$. W sektorze przedsiębiorstw średni poziom dofinansowania projektów wynosił $39,8 \%$. 


\section{Rysunek 12. Dofinansowanie projektów rozwojowych ogółem ze środków UE} w powiecie wejherowskim ( $\mathrm{w} \%)$

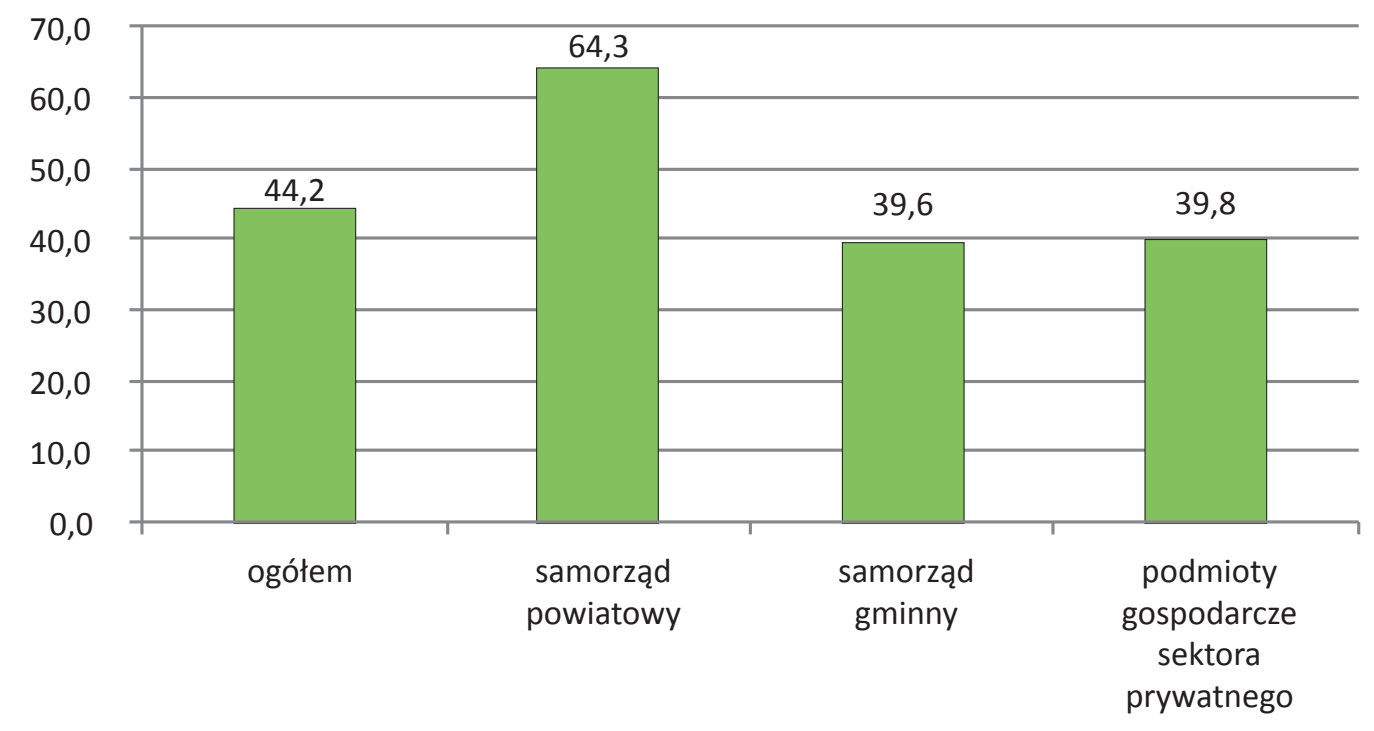

Źródło: Jak do rysunku 1.

W powiecie wołomińskim ogólna wartość projektów, dla których zawarto umowę lub aneks do umowy, począwszy od roku 2010, wyniosła ponad 1605,4 mln zł, z czego dofinansowanie unijne w tym czasie wyniosło 847,6 mln zł. Wśród analizowanych kategorii najwięcej środków wydatkowano na realizację przedsięwzięć w zakresie „Badań oraz wspierania innowacyjności”. Na tę kategorię projektów podpisano umowy na łączną kwotę ponad 407,7 mln zł, przy jednoczesnym planowanym dofinansowaniu na poziomie ponad 229,7 mln zł. Drugą pozycję zajmowały przedsięwzięcia w sferze „Efektywnego wykorzystanie zasobów”. Ogólna wartość zawartych umów w tej kategorii wyniosła powyżej $274,9 \mathrm{mln}$ zł, przy dofinansowaniu ze strony Unii Europejskiej na poziomie 144,8 mln zł. Istotne znaczenie miały również wydatki na „Wsparcie dla biznesu (w tym MŚP)” oraz „Zapewnienie spójności społecznej i terytorialnej". W tych dwóch grupach wydatki zaplanowano odpowiednio na poziomie $46,0 \mathrm{mln} \mathrm{zł}$ oraz $34,5 \mathrm{mln} \mathrm{zl}$, przy dofinansowaniu odpowiednio na poziomie 17,9 mln zł i 20,1 mln zł. Szczegółowe dane przedstawiono w tabeli 16 oraz na rysunkach 13 i 14 . 
Tabela 16. Wydatki unijne ogółem w powiecie wołomińskim na rzecz projektów przewodnich realizowanych zgodnie z celami Strategii Europa 2020 (w zl)

\begin{tabular}{|l|r|r|r|r|}
\hline \multicolumn{1}{|c|}{ Wyszczególnienie } & Wartość ogółem & \multicolumn{1}{c|}{$\begin{array}{c}\text { Wydatki } \\
\text { kwalifikowane }\end{array}$} & Dofinansowanie & \multicolumn{1}{c|}{$\begin{array}{c}\text { Dofinansowanie } \\
\text { UE }\end{array}$} \\
\hline $\begin{array}{l}\text { Badania i wspieranie } \\
\text { innowacyjności }\end{array}$ & 407700613,7 & 349851385,2 & 268552913,4 & 229782843,6 \\
\hline Poprawa systemów kształcenia & 6650549,5 & 6447606,1 & 5480465,1 & 5480465,1 \\
\hline $\begin{array}{l}\text { Upowszechnienie internetu } \\
\text { i cyfryzacja }\end{array}$ & 20227483,0 & 20139716,0 & 18804614,5 & 17118758,6 \\
\hline $\begin{array}{l}\text { Efektywne wykorzystanie } \\
\text { zasobów }\end{array}$ & 274992030,2 & 181811242,6 & 145201675,5 & 144817095,3 \\
\hline $\begin{array}{l}\text { Wsparcie dla biznesu } \\
\text { (w tym MŚP) }\end{array}$ & 46040706,1 & 38048392,9 & 21052888,5 & 17894955,1 \\
\hline $\begin{array}{l}\text { Modernizacja rynku pracy, rozwój } \\
\text { umiejętności i zatrudnienie }\end{array}$ & 0,0 & 0,0 & 0,0 & 0,0 \\
\hline $\begin{array}{l}\text { Zapewnienie spójności } \\
\text { społecznej i terytorialnej }\end{array}$ & 34535546,8 & 32109505,6 & 20108978,1 & 20103350,1 \\
\hline Inne projekty & 815274824,1 & 598001274,9 & 561258973,5 & 412397547,7 \\
\hline Ogółem & 1605421753,5 & 1226409123,2 & 1040460508,6 & 847595015,5 \\
\hline
\end{tabular}

Źródło: Jak do tabeli 1.

\section{Rysunek 13. Struktura wydatków w powiecie wołomińskim według kategorii celów} Strategii Europa 2020 oraz dofinansowanie projektów współfinansowanych ze środków UE (w \%)

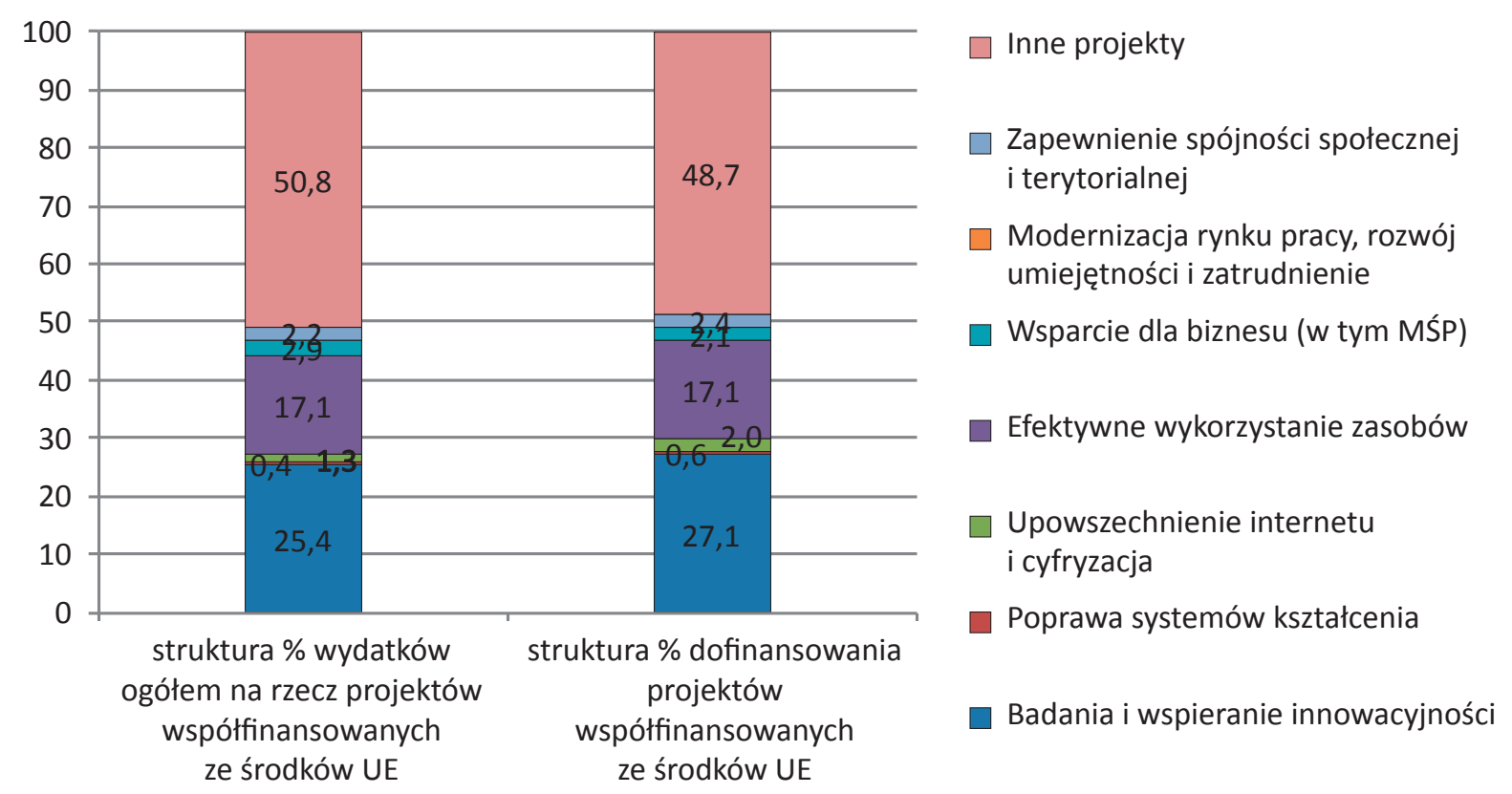

Źródło: Jak do rysunku 1. 
Rysunek 14. Dofinansowanie ogółem projektów rozwojowych w powiecie wołomińskim ze środków UE według kategorii celów Strategii Europa 2020 (w \%)

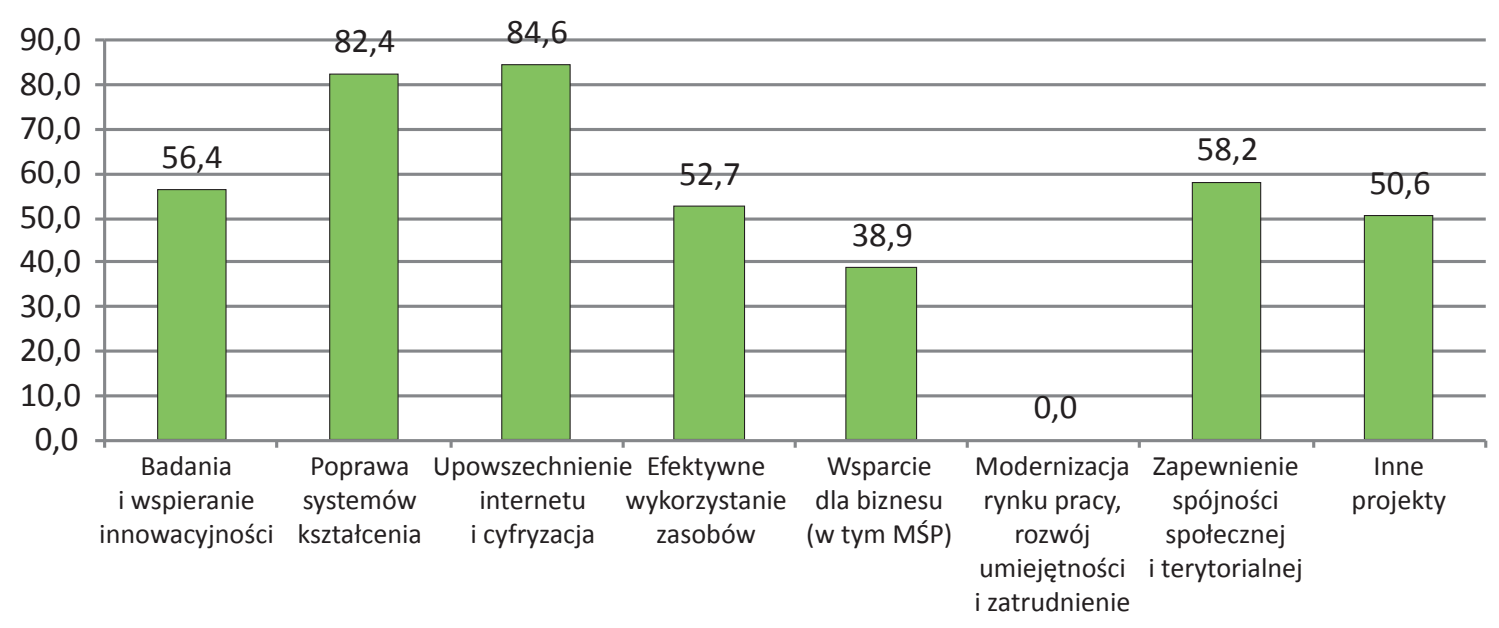

Źródło: Jak do rysunku 1.

W przypadku projektów przewidzianych do realizacji na poziomie samorządu powiatowego ogółem wolumen wydatków wyniósł ponad 21,1 mln zł, przy jednoczesnym dofinansowaniu na poziomie 13,4 mln zł. Szczegółowe dane dotyczące sytuacji w zakresie finansowania projektów na poziomie samorządu powiatowego przedstawiono w tabeli 17. Najważniejszą grupą objętą wsparciem były przedsięwzięcia z kategorii „Zapewnienie spójności społecznej i terytorialnej”, gdzie łączna wartość projektów wyniosła 13,3 mln zł, przy dofinansowaniu wynoszącym ponad 6,7 mln zł. Drugą co do wartości grupę projektów objętych wsparciem stanowiło „Upowszechnienie internetu i cyfryzacja”. Na tę grupę projektów zawarto umowy na łączną kwotę 2,2 mln zł, przy czym w kwocie tej wsparcie unijne zostało zaplanowane na poziomie $1,8 \mathrm{mln}$ zł. W powiecie wołomińskim stosunkowo znaczne wydatki przewidziano w kategorii „Inne projekty”, gdzie łączna wartość projektów wyniosła 5,6 mln zł, zaś łączna wartość dofinansowania - 4,8 mln zł. W pozostałych kategoriach nie odnotowano żadnych wydatków. Oznacza to, że z punktu widzenia urzeczywistniania celów Strategii Europa 2020 na poziomie samorządu powiatu wołomińskiego w latach 2010-2013 nie odnotowano wyraźnej aktywności

8 Ibidem, s. 50. 
Tabela 17. Wydatki unijne powiatu wołomińskiego na rzecz projektów przewodnich realizowanych zgodnie z celami Strategii Europa 2020 (w zl)

\begin{tabular}{|l|c|c|c|c|}
\hline \multicolumn{1}{|c|}{ Wyszczególnienie } & Wartość ogótem & $\begin{array}{c}\text { Wydatki } \\
\text { kwalifikowane }\end{array}$ & Dofinansowanie & $\begin{array}{c}\text { Dofinansowanie } \\
\text { UE }\end{array}$ \\
\hline $\begin{array}{l}\text { Badania i wspieranie } \\
\text { innowacyjności }\end{array}$ & 0,0 & 0,0 & 0,0 & 0,0 \\
\hline Poprawa systemów kształcenia & 0,0 & 0,0 & 0,0 & 0,0 \\
\hline $\begin{array}{l}\text { Upowszechnienie internetu } \\
\text { i cyfryzacja }\end{array}$ & 2159134,0 & 2159134,0 & 1835263,9 & 1835263,9 \\
\hline $\begin{array}{l}\text { Efektywne wykorzystanie } \\
\text { zasobów }\end{array}$ & 0,0 & 0,0 & 0,0 & 0,0 \\
\hline $\begin{array}{l}\text { Wsparcie dlla biznesu } \\
\text { (w tym MŚP) }\end{array}$ & 0,0 & 0,0 & 0,0 & 0,0 \\
\hline $\begin{array}{l}\text { Modernizacja rynku pracy, rozwój } \\
\text { umiejętności i zatrudnienie }\end{array}$ & 0,0 & 0,0 & 0,0 & 0,0 \\
\hline $\begin{array}{l}\text { Zapewnienie spójności } \\
\text { społecznej i terytorialnej }\end{array}$ & 13291895,8 & 10865854,6 & 6725964,0 & 6725964,0 \\
\hline Inne projekty & 5636811,3 & 5636811,3 & 4791289,6 & 4791289,6 \\
\hline Ogółem & 21087841,0 & 18661799,8 & 13352517,4 & 13352517,4 \\
\hline
\end{tabular}

Źródło: Jak do tabeli 1.

Jednostki samorządu terytorialnego na poziomie gmin stanowiły w powiecie wołomińskim znaczącą grupę podmiotów realizujących projekty objęte dofinansowaniem ze środków UE. Ogółem na terenie omawianego powiatu w gminach podpisano umowy na łączną wartość projektów w wysokości powyżej 162,9 mln zł, przy dofinansowaniu w wysokości 108,9 mln zł. Największą wartość projektów odnotowano w grupie „Efektywne wykorzystanie zasobów” - ponad 43,5 mln zł. Drugą co do wielkości grupę projektów zbieżnych z celami Strategii Europa 2020, poza kategorią „Inne projekty”, stanowiły wydatki zaplanowane od roku 2010 na „Zapewnienie spójności społecznej i terytorialnej". W tej grupie łączne zaplanowane wydatki wyniosły ponad 21,1 mln zł, przy zaplanowanym wsparciu ze strony UE w wysokości ponad 13,3 mln zł. Trzecią grupę projektów zbieżnych z celami Strategii Europa 2020 stanowiła kategoria „Upowszechnienie internetu i cyfryzacja”, w której wydatki ogółem wyniosły 18,1 mln zł, natomiast wsparcie unijne - 15,3 mln zł.

W gminach powiatu wołomińskiego nie zrealizowano wydatków związanych z projektami ujętymi w grupach „Badania i wspieranie innowacyjności”, „Wsparcie dla biznesu (w tym MŚP)” oraz „Modernizacja rynku pracy, rozwój umiejętności i zatrudnienie". Szczegółowe dane dotyczące wydatków unijnych gmin powiatu wołomińskiego na rzecz projektów przewodnich realizowanych zgodnie z celami Strategii Europa 2020 przedstawiono w tabeli 18. 
Tabela 18. Wydatki unijne gmin powiatu wołomińskiego na rzecz projektów przewodnich realizowanych zgodnie z celami Strategii Europa 2020 (w zl)

\begin{tabular}{|l|c|c|c|c|}
\hline \multicolumn{1}{|c|}{ Wyszczególnienie } & Wartość ogółem & $\begin{array}{c}\text { Wydatki } \\
\text { kwalifikowane }\end{array}$ & Dofinansowanie & $\begin{array}{c}\text { Dofinansowanie } \\
\text { UE }\end{array}$ \\
\hline $\begin{array}{l}\text { Badania i wspieranie } \\
\text { innowacyjności }\end{array}$ & 0,0 & 0,0 & 0,0 & 0,0 \\
\hline Poprawa systemów kształcenia & 6650549,5 & 6447606,1 & 5480465,1 & 5480465,1 \\
\hline $\begin{array}{l}\text { Upowszechnienie internetu } \\
\text { i cyfryzacja }\end{array}$ & 18068349,0 & 17980582,0 & 16969350,6 & 15283494,7 \\
\hline $\begin{array}{l}\text { Efektywne wykorzystanie } \\
\text { zasobów }\end{array}$ & 43566115,8 & 37493653,0 & 28374056,8 & 28374056,8 \\
\hline $\begin{array}{l}\text { Wsparcie dlla biznesu } \\
\text { (w tym MŚP) }\end{array}$ & 0,0 & 0,0 & 0,0 & 0,0 \\
\hline $\begin{array}{l}\text { Modernizacja rynku pracy, rozwój } \\
\text { umiejętności i zatrudnienie }\end{array}$ & 0,0 & 0,0 & 0,0 & 0,0 \\
\hline $\begin{array}{l}\text { Zapewnienie spójności } \\
\text { społecznej i terytorialnej }\end{array}$ & 21190051,0 & 21190051,0 & 13345494,1 & 13345494,1 \\
\hline Inne projekty & 73401122,5 & 54593466,7 & 46404446,7 & 46404446,7 \\
\hline Ogółem & 162876187,9 & 137705358,8 & 110573813,3 & 108887957,4 \\
\hline
\end{tabular}

Źródło: Jak do tabeli 1.

W zakresie projektów podejmowanych w sferze przedsiębiorstw wolumen wydatków ogółem wyniósł ponad 1 421,5 mln zł, przy jednoczesnym dofinansowaniu na poziomie 725,4 mln zł. Szczegółowe dane dotyczące finansowania projektów na poziomie przedsiębiorstw przedstawiono w tabeli 19. Najważniejszą grupę objętą wsparciem stanowiły przedsięwzięcia w kategorii „Inne projekty”, gdzie łączna wartość projektów wyniosła 736,2 mln zł, przy dofinansowaniu wynoszącym ponad 361,2 mln zł. Drugą co do wartości grupę projektów objętych wsparciem stanowiły „Badania i wspieranie innowacyjności”. Na tę grupę projektów zawarto umowy na łączną kwotę 407,7 mln zł, przy czym w kwocie tej wsparcie unijne zostało zaplanowane na poziomie $229,7 \mathrm{mln}$ zł. Trzecią co do wartości grupę projektów objętych wsparciem stanowiło „Efektywne wykorzystanie zasobów”. Na tę grupę projektów zawarto umowy na łączną kwotę 231,4 mln zł, przy czym w kwocie tej wsparcie unijne zostało zaplanowane na poziomie $116,4 \mathrm{mln}$ zł. W przedsiębiorstwach powiatu wołomińskiego warto odnotować również wydatki na „Wsparcie dla biznesu (w tym MŚP)” oraz „Zapewnienie spójności społecznej i terytorialnej”. 
Tabela 19. Wydatki unijne podmiotów gospodarczych sektora prywatnego w powiecie wołomińskim na rzecz projektów przewodnich realizowanych zgodnie z celami Strategii Europa 2020 (w zl)

\begin{tabular}{|l|c|c|c|c|}
\hline \multicolumn{1}{|c|}{ Wyszczególnienie } & Wartość ogótem & $\begin{array}{c}\text { Wydatki } \\
\text { kwalifikowane }\end{array}$ & Dofinansowanie & $\begin{array}{c}\text { Dofinansowanie } \\
\text { UE }\end{array}$ \\
\hline $\begin{array}{l}\text { Badania i wspieranie } \\
\text { innowacyjności }\end{array}$ & 407700613,7 & 349851385,2 & 268552913,4 & 229782843,6 \\
\hline Poprawa systemów kształcenia & 0,0 & 0,0 & 0,0 & 0,0 \\
\hline $\begin{array}{l}\text { Upowszechnienie internetu } \\
\text { i cyfryzacja }\end{array}$ & 0,0 & 0,0 & 0,0 & 0,0 \\
\hline $\begin{array}{l}\text { Efektywne wykorzystanie } \\
\text { zasobów }\end{array}$ & 231425914,5 & 144317589,6 & 116827618,7 & 116443038,5 \\
\hline $\begin{array}{l}\text { Wsparcie dlla biznesu } \\
\text { (w tym MŚP) }\end{array}$ & 46040706,1 & 38048392,9 & 21052888,5 & 17894955,1 \\
\hline $\begin{array}{l}\text { Modernizacja rynku pracy, rozwój } \\
\text { umiejętności i zatrudnienie }\end{array}$ & 0,0 & 0,0 & 0,0 & 0,0 \\
\hline $\begin{array}{l}\text { Zapewnienie spójności } \\
\text { społecznej i terytorialnej }\end{array}$ & 53600,0 & 53600,0 & 37520,0 & 31892,0 \\
\hline Inne projekty & 736236890,3 & 537770996,9 & 510063237,3 & 361201811,4 \\
\hline Ogółem & 1421457724,7 & 1070041964,6 & 916534177,9 & 725354540,7 \\
\hline
\end{tabular}

Źródło: Jak do tabeli 1.

Ze zgromadzonych danych wynika, że największą ilość środków w ramach wsparcia Unii Europejskiej absorbowały przedsiębiorstwa prywatne, które w przeważającej części kierowały środki na badania przedsięwzięć o charakterze innowacyjnym oraz na efektywne wykorzystanie zasobów (tabela 20). Taka struktura wydatków ogółem $\mathrm{w}$ powiecie wołomińskim pomiędzy sektorem prywatnym a podmiotami sektor publicznego (powiatowe oraz gminne jednostki samorządu terytorialnego) wydaje się być w pełni zgodna z cechami charakterystycznymi obszaru funkcjonalnego aglomeracji warszawskiej.

Tabela 20. Wydatki unijne ogółem według kategorii beneficjentów w powiecie wołomińskim na rzecz projektów przewodnich realizowanych zgodnie z celami Strategii Europa 2020 (w zl)

\begin{tabular}{|l|r|r|r|r|}
\hline \multicolumn{1}{|c|}{ Wyszczególnienie } & Wartość ogółem & \multicolumn{1}{c|}{$\begin{array}{c}\text { Wydatki } \\
\text { kwalifikowane }\end{array}$} & Dofinansowanie & \multicolumn{1}{c|}{$\begin{array}{c}\text { Dofinansowanie } \\
\text { UE }\end{array}$} \\
\hline Samorząd powiatowy & 21087841,0 & 18661799,8 & 13352517,4 & 13352517,4 \\
\hline Samorząd gminny & 162876187,9 & 137705358,8 & 110573813,3 & 108887957,4 \\
\hline $\begin{array}{l}\text { Podmioty gospodarcze sektora } \\
\text { prywatnego }\end{array}$ & 1421457724,7 & 1070041964,6 & 916534177,9 & 725354540,7 \\
\hline Ogółem & 1605421753,5 & 1226409123,2 & 1040460508,6 & 847595015,5 \\
\hline
\end{tabular}

Źródło: Jak do tabeli 1. 
Z rysunku 15 wynika, że podmioty sektora prywatnego absorbowały niemal 90\% ogółu nakładów skierowanych na realizację przedsięwzięć rozwojowych, przy jednoczesnym wysokim dofinansowaniu ogółem ze strony Unii Europejskiej - nieco ponad $85 \%$ kwoty dofinansowania w powiecie ogółem. Wartość projektów przewidzianych do realizacji w ramach struktur samorządu powiatowego stanowiła zaledwie 1,3\% wartości projektów ogółem, przy jednoczesnej absorpcji 1,6\% wartości dofinansowania ze środków UE, kierowanych na realizację zadań w powiecie wołomińskim ogółem. W gminnych jednostkach samorządu terytorialnego wartość projektów samorządowych wynosiła 10,1\% planowanych wydatków ogółem, przy jednoczesnym stosunkowo niskim udziale w kwocie dofinansowania ze środków UE ogółem (12,8\%).

\section{Rysunek 15. Struktura wydatków ogółem oraz dofinansowanie projektów wspólfinansowanych ze środków UE w powiecie wołomińskim w podziale według głównych grup beneficjentów (w \%)}

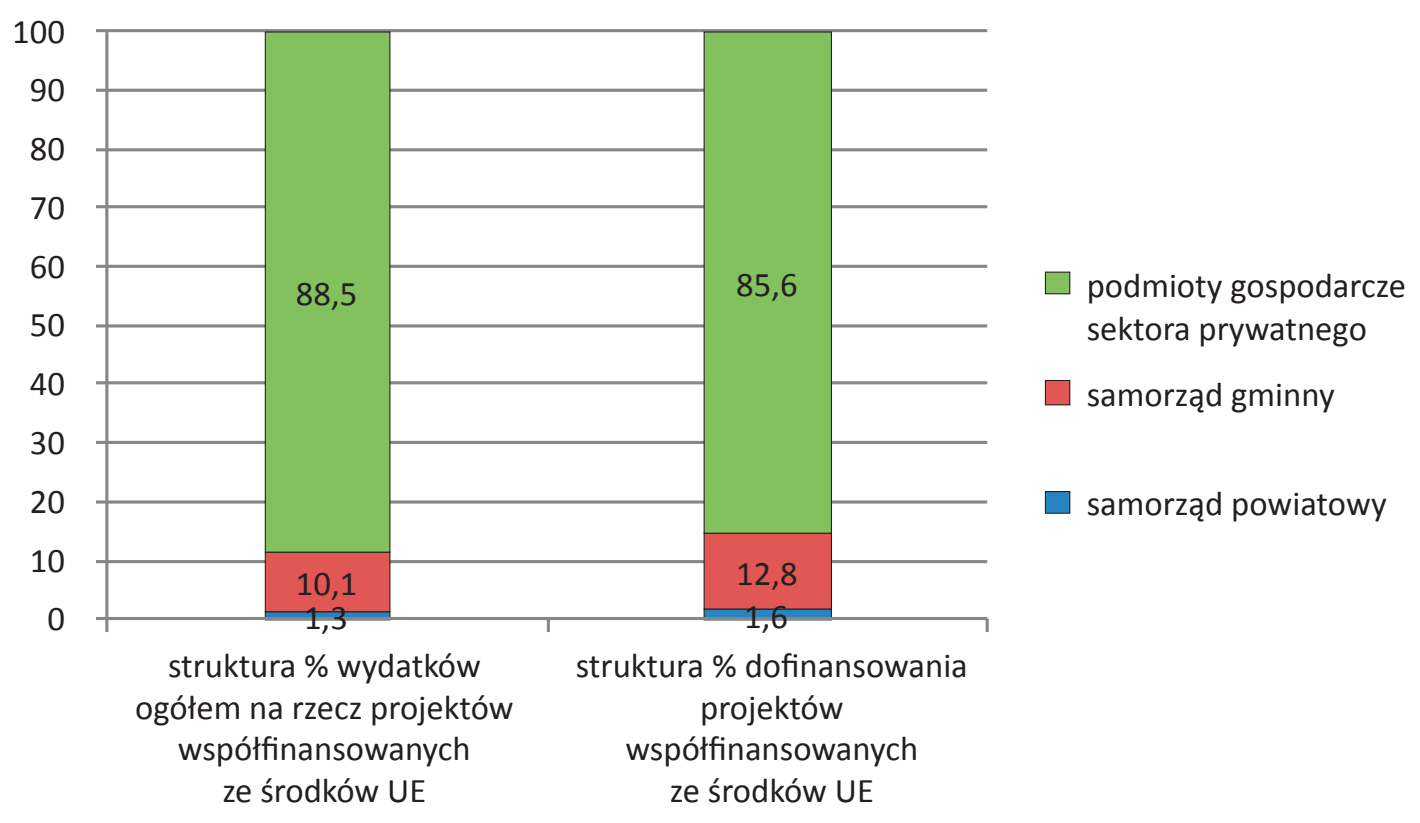

Źródło: Jak do tabeli 1.

Należy również wskazać na średni poziom dofinansowania projektów rozwojowych w zakresie powiatowych oraz gminnych jednostek samorządu terytorialnego, a także w sferze podmiotów sektora prywatnego. W odniesieniu do gmin oraz powiatu wołomińskiego średni poziom dofinansowania podjętych przedsięwzięć wynosił odpowiednio $66,9 \%$ oraz $63,3 \%$. Natomiast w sektorze przedsiębiorstw średni poziom dofinansowania projektów wynosił 51,0\%. 
Rysunek 16. Dofinansowanie projektów rozwojowych ogółem ze środków UE w powiecie wołomińskim (w \%)

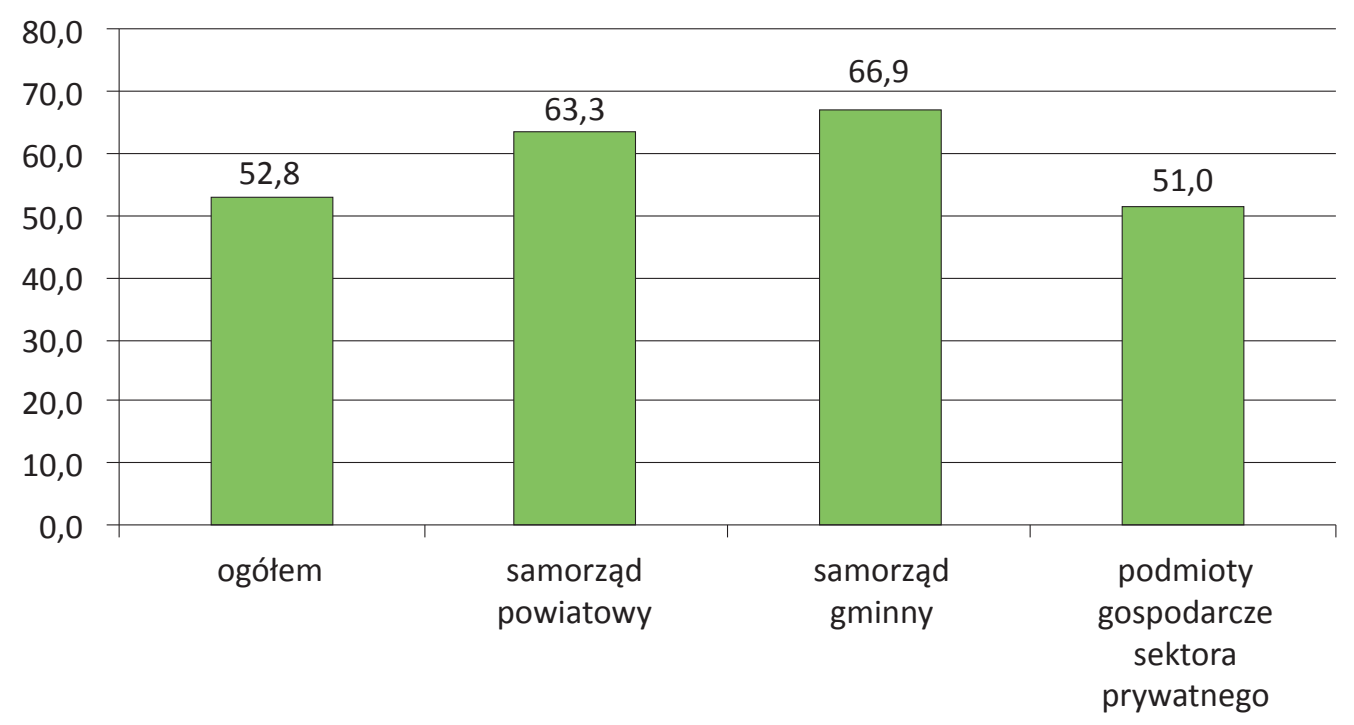

Źródło: Jak do rysunku 1.

Dokonując analizy porównawczej sytuacji w zakresie wydatków oraz poziomu dofinansowania ze środków unijnych w odniesieniu do realizowanych przedsięwzięć, należy zauważyć, że pomiędzy badanymi powiatami wystąpiły dość istotne różnice. Sytuację w tym zakresie przedstawiono w tabeli 21 . Powiat wołomiński charakteryzuje się wysokimi w porównaniu z trzema pozostałymi powiatami objętymi badaniem wydatkami projektowymi, które przekroczyły poziom $1605 \mathrm{mln}$ zł.

W celu ułatwienia analizy dodatkowo zilustrowano graficznie sytuację w badanych powiatach na rysunku 17 . Należy zaznaczyć, że sytuacja w powiecie lubelskim oraz opolskim pod wieloma względami była zbliżona. Po pierwsze, zbliżony był poziom wydatków ogółem. Po drugie, na zbliżonym poziomie kształtowały się wydatki na realizację projektów w zakresie „Badania i wspieranie innowacyjności”. Dość spore wewnętrzne różnice jeśli chodzi o wydatki na projekty realizowane pod kątem celów Strategii Europa 2020 występowały w kategoriach „Wsparcie dla biznesu (w tym MŚP)” oraz „Efektywne wykorzystanie zasobów”. 
Tabela 21. Porównanie nakładów ogółem na projekty inwestycyjne współfinansowane ze środków UE w wybranych powiatach w latach 2010-2013 (w zl)

\begin{tabular}{|l|r|r|c|r|}
\hline \multicolumn{1}{|c|}{ Wyszczególnienie } & \multicolumn{1}{c|}{ Lubelski } & \multicolumn{1}{c|}{ Opolski } & Wejherowski & \multicolumn{1}{c|}{ Wołomiński } \\
\hline Badania i wspieranie innowacyjności & 182359856,6 & 195007696,1 & 57605983,2 & 407700613,7 \\
\hline Poprawa systemów kształcenia & 13702121,4 & 7535794,7 & 25444704,8 & 6650549,5 \\
\hline Upowszechnienie internetu i cyfryzacja & 16538456,5 & 31534467,0 & 21091433,6 & 20227483,0 \\
\hline Efektywne wykorzystanie zasobów & 95318999,2 & 434715904,3 & 81365405,1 & 274992030,2 \\
\hline Wsparcie dla biznesu (w tym MŚP) & 342269876,4 & 117832887,8 & 15664815,6 & 46040706,1 \\
\hline $\begin{array}{l}\text { Modernizacja rynku pracy, rozwój } \\
\text { umiejętności i zatrudnienie }\end{array}$ & 0,0 & 0,0 & 0,0 & 0,0 \\
\hline $\begin{array}{l}\text { Zapewnienie spójności społecznej } \\
\text { i terytorialnej }\end{array}$ & 16775638,4 & 15154593,0 & 48430865,8 & 34535546,8 \\
\hline Inne projekty & 137314539,6 & 88568202,9 & 137053449,4 & 815274824,1 \\
\hline Ogółem & 804279488,1 & 890349545,9 & 386656657,4 & 1605421753,5 \\
\hline
\end{tabular}

Źródło: Jak do tabeli 1.

\section{Rysunek 17. Porównanie nakładów na projekty inwestycyjne współfinansowane} ze środków UE w wybranych powiatach w latach 2010-2013 (w mln zl)

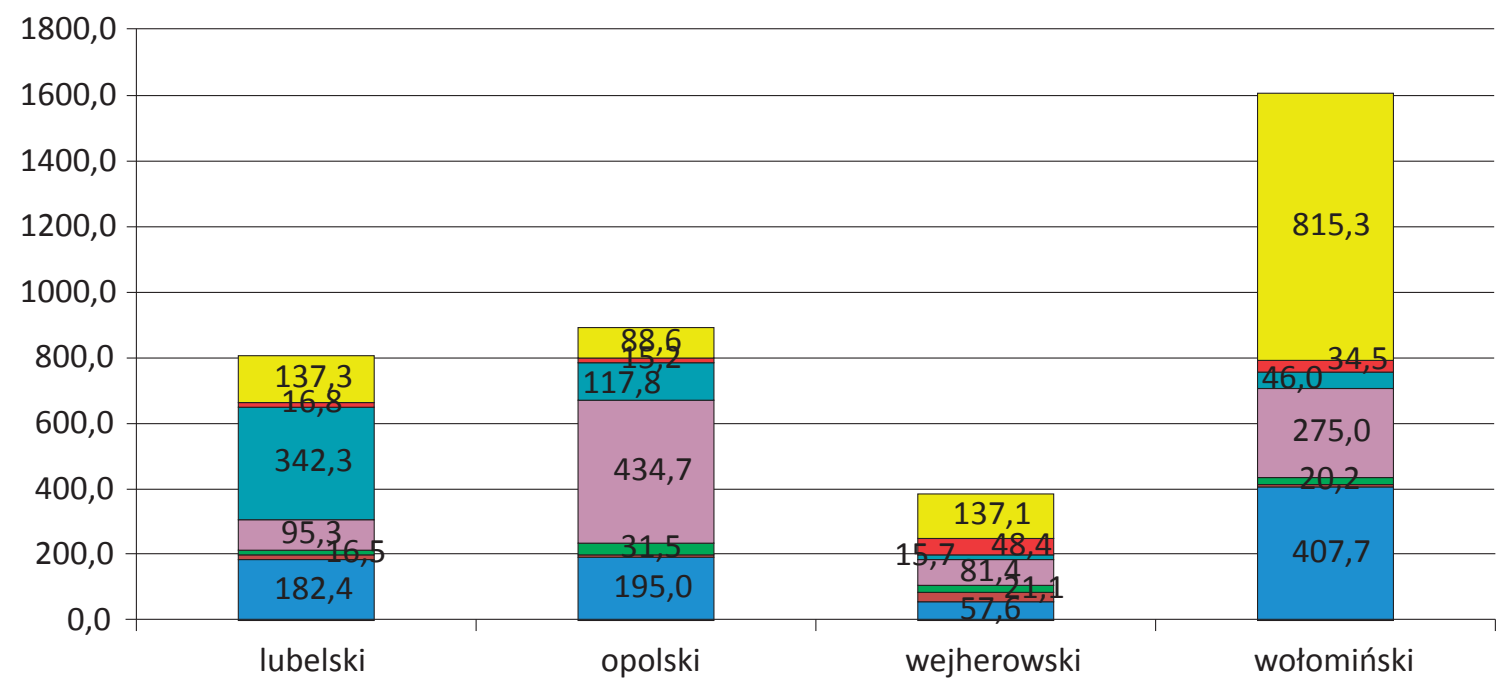

Badania i wspieranie innowacyjności

$\square$ Upowszechnienie internetu i cyfryzacja

Poprawa systemów kształcenia

$\square$ Efektywne wykorzystanie zasobów

$\square$ Modernizacja rynku pracy, rozwój umiejętności i zatrudnienie

Wsparcie dla biznesu (w tym MŚP)

$\square$ Inne projekty

Źródło: Jak do rysunku 1.

O ile w powiecie opolskim nakłady na „Efektywne wykorzystanie zasobów” kształtowały się na najwyższym poziomie spośród badanych powiatów i wynosiły $434,7 \mathrm{mln}$ zł, to już w powiecie lubelskim nakłady na tę samą kategorię wyniosły 
jedynie 95,3 mln zł i były równie niskie jak w powiecie wejherowskim. W odniesieniu do wydatków w kategorii „Wsparcie dla biznesu (w tym MŚP)” to właśnie w powiecie lubelskim odnotowano najwyższy poziom wśród badanych czterech powiatów. Nakłady te wyniosły, jak wspomniano wcześniej, 343,3 mln zł, podczas gdy w powiecie opolskim wyniosły jedynie 117,8 mln zł.

Relatywnie najgorsza sytuacja jeśli chodzi o wartościowe ujęcie analizy miała miejsce w powiecie wejherowskim. Odnotowano tam najniższy wolumen wydatków ogółem, a także bardzo niski poziom wydatków na poszczególne kategorie wyodrębnione zgodnie z celami szczegółowymi Strategii Europa 2020. Warto zwrócić uwagę na wydatki w ramach kategorii „Inne projekty”, gdzie zaliczono m.in. infrastrukturę techniczną (głównie drogi lokalne), jednakże projekty z tej kategorii nie spełniają kryteriów wynikających z celów Strategii. Należy przypuszczać, że na ogólną sytuację w badanych powiatach miały wpływ zarówno czynniki o charakterze endogenicznym, jak i czynniki zewnętrzne w stosunku do powiatu. Można określić jako wysoce prawdopodobne, że jedną z głównych przyczyn są czynniki lokalizacyjne i funkcjonalne.

\section{Podsumowanie}

Na podstawie dotychczasowych doświadczeń Polskę można wskazać jako przykład zastosowania dobrych rozwiązań w zakresie rozwoju infrastruktury technicznej oraz społecznej. Okres transformacji społeczno-gospodarczej wyraźnie dowodzi, że nastąpiło przyspieszenie tempa nakładów inwestycyjnych, zwiększenie zakresu osiągniętych efektów rzeczowych i co za tym idzie wyraźne zmniejszenie dysproporcji rozwojowych w tym zakresie pomiędzy Polską a krajami wysoko rozwiniętymi. Przyczyniły się do tego opracowywane w Polsce oraz wdrożone programy o charakterze branżowym, jak również dyscyplina w zakresie zarządzania, finansowania oraz uruchamiania poszczególnych przedsięwzięć o charakterze infrastrukturalnym.

Mając na uwadze dotychczasowe wyniki badań odnoszące się do wydatków kierowanych na realizację przedsięwzięć inwestycyjnych współfinansowanych ze środków Unii Europejskiej w wybranych czterech powiatach w Polsce, należy podkreślić, że trzy z wybranych powiatów: lubelski, opolski oraz wejherowski są obszarami funkcjonalnie powiązanymi z miastami stanowiącymi stolice województw oraz w jednym przypadku - powiatu wołomińskiego - powiązane z miastem stołecznym Warszawa 
i jednocześnie wchodzącym w skład obszaru metropolitalnego stolicy. We wszystkich czterech przypadkach peryferyjność obszarów powiatów przesądza o kierunkach oraz możliwościach szybkiego rozwoju. Wobec tego w wymienionych powiatach - poza wyróżniającym się powiatem wołomińskim - obserwuje się bardzo niskie zainteresowanie rozwojem biznesu, bardzo niski poziom zainteresowania spójnością społeczną i terytorialną oraz bardzo niskie zainteresowanie poprawą systemów kształcenia. Nie jest wykluczone, że te obszary peryferyjne urzeczywistniają własne cele rozwojowe, wśród których na pierwszym miejscu mogą znajdować się zagospodarowanie przestrzenne, ochrona środowiska, rozwijanie funkcji społecznych (w tym mieszkaniowych), a niekoniecznie funkcji stricte rozwojowych i gospodarczych.

Nieco inna sytuacja występowała ponadto w powiecie wejherowskim, który zlokalizowany jest również peryferyjnie, jednak w pewnym oddaleniu od aglomeracji gdańskiej. Mimo to obszar powiatu wejherowskiego właśnie z uwagi na lokalizację przejawia inne ważne funkcje związane z rozwojem turystki i gospodarki morskiej. Należy również pamiętać, że powiat wejherowski to obszar rolniczo-leśny, w związku $z$ tym realizowane są dotychczasowe, historycznie ukształtowane funkcje. Autorzy opracowania nie oceniają tego negatywnie, stojąc na stanowisku, że demokracja lokalna daje pełne prawo społecznościom lokalnym wyboru własnej ścieżki rozwoju i kształtowania przyszłości. Z tych też względów, nawet jeśli nie odnotowuje się wysokich nakładów na biznes i gospodarkę w wąskim znaczeniu, należy zawsze mieć na względzie priorytety społeczności lokalnych i w takim rozumieniu kojarzyć środki unijne z celami w ramach Strategii Europa 2020.

Wyniki przeprowadzonego badania wyraźnie pokazują wzrastające znaczenie „samorządowego podejścia” do szeregu spraw społecznych, na które władze publiczne mają wpływ na poziomie lokalnym. Na pierwszy plan wysuwa się tutaj rozwijanie usług społecznych na poziomie regionalnym i lokalnym, przy jednoczesnym zawężaniu zakresu inwestycji z obszaru infrastruktury technicznej. Z uwagi na ograniczone ramy opracowania nie zaprezentowano wyników dla większej liczby powiatów oraz gmin w Polsce. Badania te będą jednak prowadzone w celu szerszego rozpoznania wpływu polityki spójności Unii Europejskiej na rozwój lokalny. W warunkach gospodarki rynkowej oraz przedłużającego się okresu spowolnienia gospodarczego sfera zadań społecznych może napotykać trudności w organizowaniu oraz finansowaniu wielu usług. Trudności te mogą być bardziej dotkliwe, jeśli rozwój społeczno-gospodarczy pozbawiony będzie wsparcia środkami publicznymi wobec zwiększonych wymogów o charakterze proefektywnościowym w ramach formuły liberalizowania gospodarki. 


\section{Financing local investment projects in Poland in 2010-2013}

The paper contains the results of regional studies conducted for the compliance of development projects with the objectives of the Europe 2020 Strategy, and with a particular focus on innovative projects. The specific aim of the study was to analyze the projects for which contracts for co-financing from EU funds have been concluded, and which are consistent with both the priorities of the Strategy, and the general objectives of the European Union up to 2020. The analysis was conducted in groups of projects corresponding to the objectives of the Strategy. The results of the study clearly showed the diversity (in terms of financial value and quantitative measure) of development projects at two levels of local government: district (powiat) administration and municipal administration, as well as the role of private sector activity in implementing innovations. Especially noticeable was strengthening of "self-government approach" to social issues, which are in the scope of an impact of the public authorities at regional and local level. Growing importance of the social services development coincides with the gradual decreasing of the scope of investments in technical infrastructure. Meanwhile the activity in the field of innovation focused clearly in the private sector units.

Keywords: EU funds, innovations, financing innovative projects

\section{Le financement des projets de développement au niveau local en Pologne dans les années 2010-2013}

Le document contient les résultats des études régionales menées pour la conformité des projets de développement avec les objectifs de la Stratégie Europe 2020, et avec un accent particulier sur les projets innovants. L'objectif spécifique de létude était d'analyser les projets pour lesquels des contrats de co-financement des fonds européens ont été conclus, et qui sont compatibles avec les deux priorités de la Stratégie et les objectifs généraux de l'Union européenne jusquà 2020. Lanalyse a été menée dans des groupes de projets correspondant aux objectifs de la Stratégie. Les résultats de létude montrent clairement la diversité (en termes de valeur financière et mesure quantitative) des projets de développement à deux niveaux de gouvernement local: l'administration du district (powiat) et l'administration municipale, ainsi que le rôle de l'activité du secteur privé dans la mise en œuvre des innovations. Au cours de létude on a enregistré une importance croissante de l'approche basée sur le collectivités territoriales à de nombreuses questions sociales, sur lesquelles les autorités publiques ont un impact sur le niveau régional 
et local. On a observé le développement des services sociaux tout en réduisant la portée des investissements dans les infrastructures techniques. Pendant ce temps l'activité dans le domaine de l'innovation a été concentré dans le secteur privé.

Mots-clés: les fonds de l'UE, les innovations, le financement des projets innovants

\section{Финансирование инвестиционных проектов на местном уровне в Польше в 2010-2013 гг.}

В статье содержатся результаты региональных анализов соответствия проектов в сфере развития, в особенности инновационных проектов, целям Стратегии Европа 2020. Предметом исследования стали проекты, которые по заключенным договорам должны быть финансированы из фондов ЕС, соответствуют приоритетам Стратегии и общим целям Европейского союза до 2020 года. Проекты подвергнутые анализу были разделены на группы, учитывая цели стратегии. Результаты исследования наглядно продемонстрировали разнообразие (в плане финансовой стоимости и количественных параметров) проектов в области развития на двух уровнях местного самоуправления: района (повята) и муниципального управления, а также роль частного сектора в реализации инноваций. Особенно заметно стало укрепление "самоуправленческого подхода" к социальным вопросам - сфере, которая находится под влиянием органов государственной власти на региональном и местном уровнях. Растущие значение развития социальных услуг совпадает с постепенным уменьшением объема инвестиций в техническую инфраструктуру, а инновационная деятельность явно сосредоточена в частном секторе.

Ключевые слова: финансирование ЕС, инновации, финансирование инновационных проектов 